\title{
Обзоры
}

Пространственная Экономика

2011. № 2. C. 54-91

УДК 338.2(571.6)

О. М. Прокапало, А. Г. Исаев, $\Delta$. В. Суслов,

Е. И. $\Delta$ еваева, Т. Е. Котова

ЭКОНОМИЧЕСКАЯ

KOHЬЮHКTYPA

В $\triangle$ АЛЬHЕВОСТОЧНОМ

ФЕ $\triangle$ EPA^ЬHOM OKРУГE В 2010 r.

На основе официальной оперативной статистической информации за 2010 г. оценены тенденции социально-экономического развития Дальневосточного федерального округа. Рассмотрены общеэкономическая ситуация, текущая ситуация в сфере производства товаров и услуг, социальной сфере, параметры внешнеэкономического сотрудничества.

ВРП, промышленность, финансы, инфляция, доходы населения, рынок труда, иностранные инвестиции, внешняя торговля, Дальневосточный федеральный округ.

\section{ОБЩЕЭКОНОМИЧЕСКАЯ СИТУАЦИЯ}

Социально-экономическое развитие Российской Федерации в 2010 г. продолжалось под влиянием последствий мирового финансового кризиса. В Дальневосточном федеральном округе (ДФО) проявление кризисных шоков было менее болезненным, чем в российской экономике, что связано со структурными особенностями экономики, а также с инвестиционными предпочтениями государства и бизнеса. Результатом этого явилось опережающее развитие экономики Дальнего Востока России относительно общефедерального уровня (табл. 1).

( С Прокапало О. М., Суслов Д. В., Исаев А. Г., Деваева Е. И., Котова Т. Е., 2011

Статья подготовлена при поддержке гранта РГНФ № 11-02-00566а; проектов № 09-I-П24-01, № 09-I-OOH-01. 
Динамика основных макропоказателей РФ и ДФО, в \% к предыдущему году

Таблииа 1

\begin{tabular}{|c|c|c|c|c|c|c|c|c|}
\hline \multirow[t]{2}{*}{ Показатель } & \multicolumn{2}{|c|}{2008} & \multicolumn{2}{|c|}{2009} & \multicolumn{2}{|c|}{2010} & \multicolumn{2}{|c|}{$\begin{array}{c}\text { Справочно, } \\
2010 \text { в \% к } \\
2007\end{array}$} \\
\hline & РФ & ДФО & РФ & ДФО & РФ & ДФО & РФ & ДФО \\
\hline $\begin{array}{l}\text { Валовой внутренний } \\
\text { (региональный) продукт }\end{array}$ & 105,7 & 103,4 & 92,4 & 101,5 & 104,0 & $106,9^{*}$ & 101,6 & 112,2 \\
\hline $\begin{array}{l}\text { Объем промышленной } \\
\text { продукции }\end{array}$ & 100,6 & 99,1 & 90,7 & 103,9 & 108,2 & 107,4 & 98,7 & 110,6 \\
\hline $\begin{array}{l}\text { Инвестиции в основной } \\
\text { капитал }\end{array}$ & 109,9 & 111,7 & 83,8 & 129,9 & 106,0 & 98,1 & 97,6 & 142,3 \\
\hline $\begin{array}{l}\text { Грузооборот во всем видам } \\
\text { транспорта }\end{array}$ & 100,7 & 103,8 & 89,8 & 102,8 & 106,9 & 122,7 & 96,7 & 130,9 \\
\hline Экспорт & 132,7 & 112,6 & 64,5 & 85,1 & 131,4 & 148,21 & 112,5 & 142,0 \\
\hline $\begin{array}{l}\text { Ввод в действие жилых } \\
\text { домов }\end{array}$ & 104,6 & 109,5 & 93,5 & 106,6 & 97,0 & 107,6 & 94,9 & 125,6 \\
\hline $\begin{array}{l}\text { Реальная среднемесячная } \\
\text { заработная плата }\end{array}$ & 111,5 & 110,3 & 96,5 & 98,8 & 104,6 & 104,6 & 112,5 & 114,0 \\
\hline
\end{tabular}

Примечание. * Предварительные данные.

Источники: [12;13;17].

Из-за незначительного спада промышленного производства в ДФО в период кризиса $(0,9 \%)$ задача восстановления экономики была менее сложной, чем для страны в целом. В 2010 г. темпы роста по основным макроэкономическим параметрам относительно 2007 г. были стабильно положительными и значительно превышали базовый уровень. Это тем более заметно на фоне развития российской экономики, в которой объемы в промышленности, строительстве, на транспорте, инвестиционной активности в 2010 г. так и не достигли уровня предкризисного 2007 г. (табл. 2).

Таблица 2

Динамика промышленного производства*, в \% к предыдущему периоду

\begin{tabular}{l|c|c|c|c|c}
\hline \multicolumn{1}{c|}{ Территория } & 2006 & 2007 & 2008 & 2009 & 2010 \\
\hline \multicolumn{1}{c|}{1} & 2 & 3 & 4 & 5 & 6 \\
\hline Российская Федерация** & 106,3 & 106,8 & 100,6 & 90,7 & 108,2 \\
\hline ДФО & 104,2 & 122,6 & 99,1 & 103,9 & 107,4 \\
\hline Республика Саха (Якутия) & 100,0 & 100,2 & 103,5 & 92,8 & 117,5 \\
\hline Камчатский край & 101,6 & 103,9 & 103,0 & 99,7 & 105,0 \\
\hline Приморский край & 112,6 & 101,0 & 108,6 & 95,8 & 111,5 \\
\hline Хабаровский край & 89,3 & 109,1 & 87,9 & 94,3 & 124,7 \\
\hline Амурская область & 104,7 & 106,4 & 111,5 & 109,3 & 104,6 \\
\hline Магаданская область & 88,8 & 92,7 & 101,1 & 105,6 & 103,8 \\
\hline
\end{tabular}


№ 22011

\begin{tabular}{l|c|c|c|c|c}
\hline \multicolumn{1}{c|}{1} & 2 & 3 & 4 & 5 & 6 \\
\hline Сахалинская область & 131,1 & в $2,1 \mathrm{p}$. & 87,0 & 123,8 & 101,2 \\
\hline ЕАО & 104,2 & 110,5 & 105,2 & 83,0 & 101,2 \\
\hline ЧАО & 90,9 & 88,8 & в $3,1 \mathrm{p}$. & 114,6 & 93,8 \\
\hline
\end{tabular}

Примечания. *Агрегированный индекс производства по видам экономической деятельности «Добыча полезных ископаемых», «Обрабатывающие производства», «Производство и распределение электроэнергии, газа и воды». ** С учетом поправки на неформальную деятельность.

Источники: [11-13; 17].

В течение последнего десятилетия в экономике ДФО произошли структурные сдвиги в сторону утяжеления структуры промышленного производства при снижении удельного веса продукции предприятий обрабатывающей промышленности. В 2010 г. в целом по ДФО добывающие производства в общем объеме промышленности составляли более $60 \%$, а для отдельных территорий (Сахалинская область, Чукотский автономный округ, Республика (Саха) Якутия, Магаданская область) этот показатель значительно выше (puc. 1).

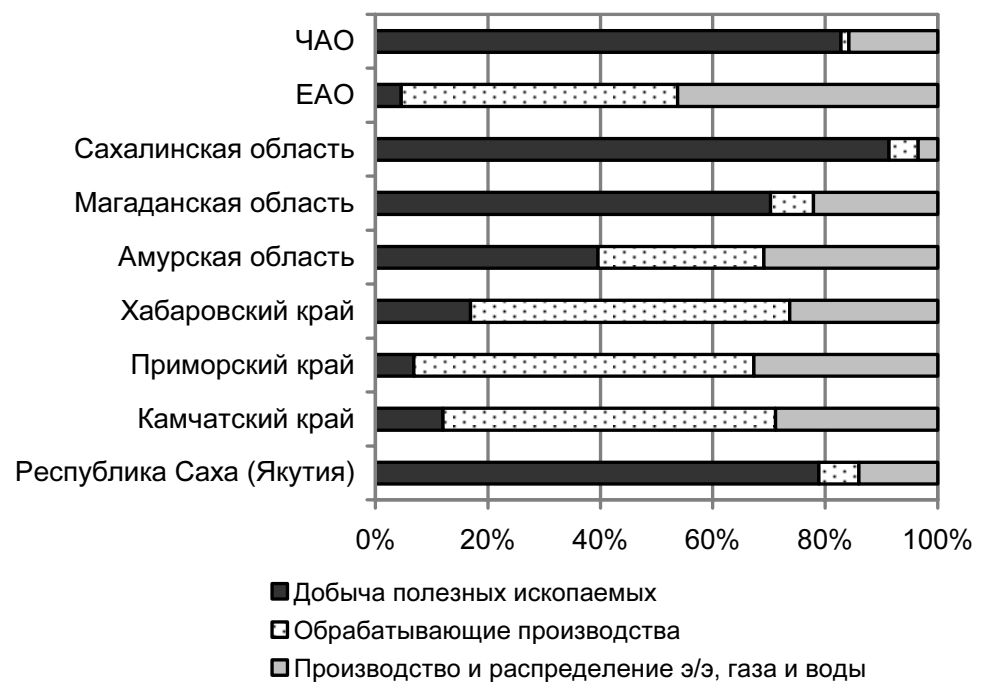

Puc. 1. Структура промышленного производства, 2010 г.

(по объемам отгруженных товаров собственного производства, выполненных собственными силами работ и услуг), \%

Значительный удельный вес добывающего сектора, в котором проявление кризисных шоков было не столь масштабным и разрушительным, как в обрабатывающем секторе, позволил экономике Дальнего Востока сократить период восстановления и быстро достичь докризисного уровня развития. 
О преодолении негативных последствий кризиса может свидетельствовать и тот факт, что в 2010 г. обрабатывающий сектор Дальнего Востока демонстрирует высокие темпы роста (126,6\% против 101,1\% в 2009 г.). Наибольший вклад в развитие обрабатывающей промышленности ДФО внесли Амурская область (рост 149,1\%) и Хабаровский край (рост 141,8\%). Успехи в Амурской области связаны с реализацией проектов на основе государственно-частного партнерства по организации сборочного производства комбайнов, строительства малых рыболовных сейнеров, производства светодиодных уличных светильников, а в Хабаровском крае - за счет выпуска продукции военного и гражданского назначения на авиационных и судостроительных предприятиях края [6].

Рост в добывающих отраслях ДФО в 2010 г. был намного скромнее, составив лишь 102,9\%, и был обеспечен в основном увеличением на 20,3\% объема добычи полезных ископаемых в Республике Саха (Якутия). Увеличение добычи полезных ископаемых в Еврейской автономной области (174,7\% относительно 2009 г.) не могло оказать существенного воздействия на формирование общерегионального темпа роста, поскольку в территориальной структуре добывающей промышленности доля области незначительна (табл. 3).

Таблица 3

Индекс промышленного производства

\begin{tabular}{l|c|c|c|c}
\hline \multicolumn{1}{|c|}{ Территория } & $\begin{array}{c}2010 \text { в \% } \\
\text { к 2009 }\end{array}$ & $\begin{array}{c}\text { Добыча } \\
\text { полезных } \\
\text { ископаемых }\end{array}$ & $\begin{array}{c}\text { Обрабатывающие } \\
\text { производства }\end{array}$ & $\begin{array}{c}\text { Производство } \\
\text { и распределение } \\
\text { электроэнергии, } \\
\text { газа и воды }\end{array}$ \\
\hline Российская Федерация & 108,2 & $\begin{array}{c}103,6 \\
(22,6)^{*}\end{array}$ & $\begin{array}{c}111,8 \\
(64,8)^{*}\end{array}$ & $\begin{array}{c}104,1 \\
(12,6)^{*}\end{array}$ \\
\hline ДФО & 107,4 & $\begin{array}{c}102,9 \\
(61,0)^{*}\end{array}$ & $\begin{array}{c}126,6 \\
(22,7)^{*}\end{array}$ & $\begin{array}{c}101,8 \\
(16,3)^{*}\end{array}$ \\
\hline Республика Саха (Якутия) & 117,5 & 120,3 & 119,6 & 100,1 \\
\hline Камчатский край & 105,0 & 123,4 & 101,4 & 99,3 \\
\hline Приморский край & 111,5 & 83,6 & 119,5 & 102,6 \\
\hline Хабаровский край & 124,7 & 98,8 & 141,8 & 99,2 \\
\hline Амурская область & 104,6 & 90,5 & 149,1 & 108,3 \\
\hline Магаданская область & 103,8 & 104,6 & 97,9 & 102,5 \\
\hline Сахалинская область & 101,2 & 99,5 & 121,6 & 104,1 \\
\hline ЕАО & 101,2 & 174,7 & 100,0 & 101,0 \\
\hline ЧАО & 93,8 & 88,4 & 94,6 & 100,1 \\
\hline
\end{tabular}

Примечания. * В скобках - удельный вес видов деятельности в общем объеме выпуска промышленной продукции в 2010 г.

Источник: [13]. 
으 2011

\section{Финансы}

Позитивные изменения в экономике привели к улучшению финансового состояния предприятий. За январь - ноябрь 2010 г. сальдированный финансовый результат деятельности организаций в целом по ДФО составил 233,1 млрд руб. (за аналогичный период прошлого года 97,9 млрд руб.). Как и в предыдущие годы, основными донорами, обеспечивающими основной приток финансовых ресурсов, являются такие сферы деятельности, как добыча полезных ископаемых, а также транспорт и связь. Прибыль крупных и средних предприятий составила 270 млрд руб., увеличившись по сравнению с 2009 г. почти в 2 раза (табл. 4).

Финансовые результаты деятельности организаций

Таблица 4 за январь - ноябрь 2010 г.

\begin{tabular}{|c|c|c|c|c|c|}
\hline \multirow[b]{2}{*}{ Территория } & \multicolumn{2}{|c|}{$\begin{array}{c}\text { Сальдо прибылей }(+) \\
\text { и убытков (-) }\end{array}$} & \multicolumn{2}{|c|}{ Прибыль } & \multirow{2}{*}{$\begin{array}{c}\text { Удельный вес } \\
\text { убыточных } \\
\text { предприятий, } \\
\%\end{array}$} \\
\hline & $\begin{array}{l}\text { млн } \\
\text { руб. }\end{array}$ & $\begin{array}{c}\text { в \% к } \\
\text { январю - } \\
\text { ноябрю } \\
2009 \text { г.* }\end{array}$ & $\begin{array}{l}\text { млн } \\
\text { руб. }\end{array}$ & $\begin{array}{c}\text { в \% к } \\
\text { январю - } \\
\text { ноябрю } \\
2009 \text { г. }\end{array}$ & \\
\hline ДФО & 233102,2 & $\ldots$ & 269630,7 & 198,8 & $\ldots$ \\
\hline Республика Саха (Якутия) & 30745,5 & в $58,5 \mathrm{p}$. & 36507,4 & в $3 \mathrm{p}$. & 35,2 \\
\hline Камчатский край & 3484,4 & 83,1 & 5904,2 & 84,9 & 30,2 \\
\hline Приморский край & 26067,8 & 165,7 & 32570,9 & 157,8 & 28,7 \\
\hline Хабаровский край & 11958,6 & 194,6 & 26885,6 & 149,5 & 34,7 \\
\hline Амурская область & 17758,5 & в $2,7 \mathrm{p}$. & 19120,2 & 190,0 & 27,8 \\
\hline Магаданская область & 6491,8 & 135,6 & 7119,1 & 125,3 & 34,9 \\
\hline Сахалинская область & 120138,8 & в $3,1 \mathrm{p}$. & 122726,2 & в $2,9 \mathrm{p}$. & 35,0 \\
\hline EAO & 239,7 & - & 411,8 & в $3,6 \mathrm{p}$. & 48,3 \\
\hline ЧАО & 16217,1 & 88,6 & 18385,3 & 93,5 & 36,8 \\
\hline
\end{tabular}

Примечание. * В фактических ценах.

Источник: [11].

Начиная со второго полугодия 2009 г. происходит процесс постепенной адаптации предприятий реального сектора к функционированию в кризисных условиях. Если по итогам пяти месяцев доля убыточных предприятий в Приморском крае составляла 35,5\% (наименьший показатель), а в Чукотском автономном округе - 60,3\% (наибольший показатель), то концу 2010 г. отмечаются тенденции к снижению данного показателя по всем территориям Дальнего Востока.

Процесс восстановления экономической активности в различных отрас- 
лях происходит неравномерно. Основной вклад в увеличение объема финансовых ресурсов обеспечивают отрасли добывающего сектора (минеральносырьевой и топливно-энергетический), что связано с постоянно высоким спросом на международном и внутреннем рынках. Анализ финансовой ситуации в разрезе основных секторов экономики подтверждает этот тезис (табл. 5).

Таблица 5

\section{Сальдированный финансовый результат крупных и средних предприятий} и организаций по основным видам деятельности в январе - ноябре 2010 г., млн руб.

\begin{tabular}{|c|c|c|c|c|c|c|c|}
\hline Территория & $\begin{array}{c}\text { Добыча } \\
\text { полезных } \\
\text { ископае- } \\
\text { мых }\end{array}$ & $\begin{array}{c}\text { Обра- } \\
\text { батыва- } \\
\text { ющие } \\
\text { произ- } \\
\text { водства }\end{array}$ & $\begin{array}{c}\text { Производ- } \\
\text { ство и рас- } \\
\text { пределение } \\
\text { электро- } \\
\text { энергии, } \\
\text { газа и воды }\end{array}$ & $\begin{array}{c}\text { Сельское } \\
\text { хозяй- } \\
\text { ство, } \\
\text { охота и } \\
\text { лесное } \\
\text { хозяй- } \\
\text { ство }\end{array}$ & $\begin{array}{c}\text { Рыбо- } \\
\text { лов- } \\
\text { ство, } \\
\text { рыбо- } \\
\text { водство }\end{array}$ & $\begin{array}{c}\text { Стро- } \\
\text { итель- } \\
\text { ство }\end{array}$ & $\begin{array}{c}\text { Транс- } \\
\text { порт } \\
\text { и связь }\end{array}$ \\
\hline $\begin{array}{l}\text { Республика } \\
\text { Саха (Якутия) }\end{array}$ & 29417,8 & 359,1 & $-2485,6$ & 372,7 & $-3,3$ & $-208,5$ & 474,4 \\
\hline $\begin{array}{l}\text { Камчатский } \\
\text { край }\end{array}$ & 197,2 & 936,4 & 331,3 & 90,4 & 2047,8 & 132,9 & $-735,4$ \\
\hline $\begin{array}{l}\text { Приморский } \\
\text { край }\end{array}$ & 1040,6 & 2114,7 & 62,6 & $-82,4$ & 3073,8 & 96,1 & 18419,4 \\
\hline $\begin{array}{l}\text { Хабаровский } \\
\text { край }\end{array}$ & 7505,7 & $-4002,7$ & 541,7 & $-184,5$ & 442,8 & 1335,4 & 1811,4 \\
\hline $\begin{array}{l}\text { Амурская } \\
\text { область }\end{array}$ & 4864,5 & 354,4 & 718,5 & 746,5 & - & 746,0 & 231,3 \\
\hline $\begin{array}{l}\text { Магаданская } \\
\text { область }\end{array}$ & 4800,1 & 190,3 & 203,6 & $-4,8$ & 223,9 & 255,2 & 113,7 \\
\hline $\begin{array}{l}\text { Сахалинская } \\
\text { область }\end{array}$ & 114148,3 & 1022,1 & $-238,8$ & 59,3 & 878,8 & 1121,5 & 1365,9 \\
\hline EAO & $-31,1$ & 33,6 & 213,7 & 30,8 & - & $-42,8$ & 13,1 \\
\hline ЧАО & 15895,9 & $-52,8$ & $-873,5$ & 5,5 & 242,6 & 231,1 & $-118,3$ \\
\hline
\end{tabular}

Источник: [11].

\section{Инвестиции}

В 2010 г. в ДФО отмечался отрицательный прирост объема инвестиций в основной капитал $(-1,9 \%)$ (табл. б).

Однако это произошло на фоне стремительного подъема $(129,9 \%)$ в 2009 г. Несмотря на отрицательные темпы прироста в 2010 г., регион сохранил за собой лидирующие позиции среди федеральных округов по совокупным объемам инвестиций за период 2009-2010 гг. (рис. 2). 
№ 22011

Таблица 6

Динамика инвестиций в основной капитал, в \% к предыдущему периоду

\begin{tabular}{l|c|c|c|c|c}
\hline \multicolumn{1}{c|}{ Территория } & 2006 & 2007 & 2008 & 2009 & 2010 \\
\hline Российская Федерация & 116,7 & 122,7 & 109,9 & 83,8 & 106,0 \\
\hline ДФО & 102,3 & 118,9 & 111,7 & 129,9 & 98,1 \\
\hline Республика Саха (Якутия) & 102,1 & 192,2 & 114,0 & 199,5 & 57,3 \\
\hline Камчатский край & 105,2 & 133,5 & 105,4 & 92,0 & 107,1 \\
\hline Приморский край & 106,4 & 120,6 & 141,5 & 160,8 & 117,1 \\
\hline Хабаровский край & 108,7 & 122,9 & 109,9 & 100,1 & 127,4 \\
\hline Амурская область & 105,1 & 138,9 & 124,1 & 134,6 & 114,0 \\
\hline Магаданская область & 123,9 & 128,7 & 115,1 & 80,4 & 80,8 \\
\hline Сахалинская область & 100,3 & 81,9 & 94,5 & 67,9 & 107,8 \\
\hline ЕАО & 98,8 & 120,3 & 104,5 & 89,8 & в 2,1 р. \\
\hline ЧАО & 61,4 & 101,6 & 129,5 & 134,5 & 31,1 \\
\hline
\end{tabular}

Источники: [11-13; 17].

Увеличение объемов инвестиционных ресурсов в дальневосточных субъектах РФ связано с реализацией крупномасштабных проектов по созданию транспортной и энергетической инфраструктуры, позволяющей обеспечить доступ и эксплуатацию минерально-сырьевых и топливно-энергетических ресурсов, востребованных на международных рынках. К таким высокозатратным проектам относятся: нефтепровод Восточная Сибирь - Тихий океан, объекты саммита АТЭС в г. Владивостоке, ресурсные проекты Южной Якутии, региональные газопроводы, сеть федеральных автодорог.

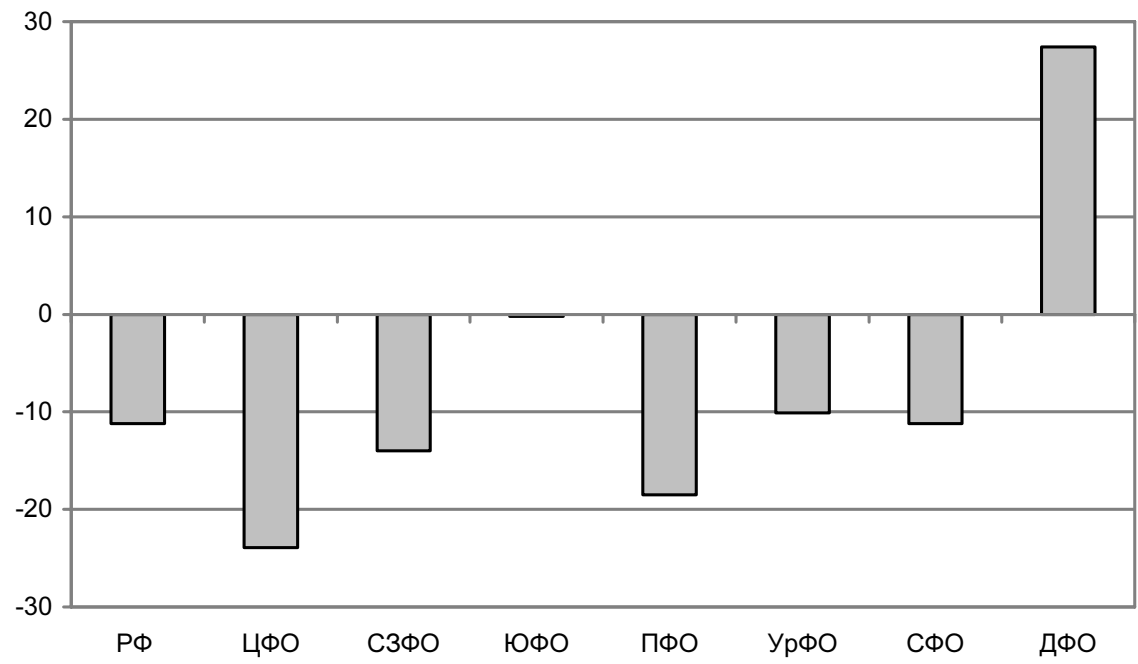

Puc. 2. Темп прироста (снижения) объема инвестиций по РФ и федеральным округам в 2010 г., \% к 2008 г. 
Территориальное распределение инвестиционных ресурсов не претерпело существенных изменений: основной объем инвестиций, совокупная доля которых в общем объеме составляла около 80\%, направлялся в Приморский и Хабаровский края, Сахалинскую область и Республику (Саха) Якутия.

В структуре инвестиций в основной капитал по источникам финансирования в целом по ДФО доля собственных средств невысока и составляет $26,3 \%$, и этот показатель превышен в Республике (Саха) Якутия $(47,7 \%)$, Сахалинской и Магаданской областях (40,0 и 27,7\% соответственно), Чукотском автономном округе $(30,8 \%)$.

\section{Инфляция}

За январь - декабрь 2010 г. инфляция на потребительском рынке в ДФО составила 7,7\%, что ниже уровня 2009 г. на 2,0 п. п. Надо отметить, что рост цен на потребительском рынке в ДФО был ниже среднероссийского уровня $(8,8 \%)$ и наименьшим среди федеральных округов. В пяти регионах (ЧАО, Республика (Саха) Якутия, Приморский и Хабаровский края, Магаданская область) значение показателя не превышало среднероссийский уровень, причем в ЧАО индекс потребительских цен был минимальным и составил $1,4 \%$ (табл. 7).

Таблица 7

Индекс потребительских цен, в \% к предыдущему периоду

\begin{tabular}{l|c|c|c|c|c}
\hline \multicolumn{1}{c|}{ Территория } & 2006 & 2007 & 2008 & 2009 & 2010 \\
\hline Российская Федерация & 109,0 & 111,9 & 113,3 & 108,8 & 109,1 \\
\hline ДФО & 108,8 & 109,6 & 113,6 & 109,7 & 107,3 \\
\hline Республика Саха (Якутия) & 111,9 & 109,0 & 112,5 & 108,2 & 104,9 \\
\hline Камчатский край & 111,6 & 110,1 & 114,8 & 110,7 & 107,2 \\
\hline Приморский край & 107,1 & 109,7 & 113,5 & 109,5 & 107,3 \\
\hline Хабаровский край & 108,7 & 109,8 & 114,1 & 109,5 & 106,9 \\
\hline Амурская область & 109,1 & 109,6 & 114,1 & 109,6 & 108,7 \\
\hline Магаданская область & 108,1 & 113,3 & 119,3 & 113,4 & 109,6 \\
\hline Сахалинская область & 110,4 & 111,8 & 113,1 & 110,7 & 111,0 \\
\hline ЕАО & 105,5 & 111,7 & 115,0 & 112,2 & 109,7 \\
\hline ЧАО & 111,2 & 107,5 & 109,9 & 117,2 & 101,1 \\
\hline
\end{tabular}

Источники: [11-13; 17].

В течение 2010 г. инфляционные процессы можно охарактеризовать как умеренно поступательные. Рост цен продолжался в течение всего года, но темп относительно предыдущего года значительно снизился (рис. 3). 

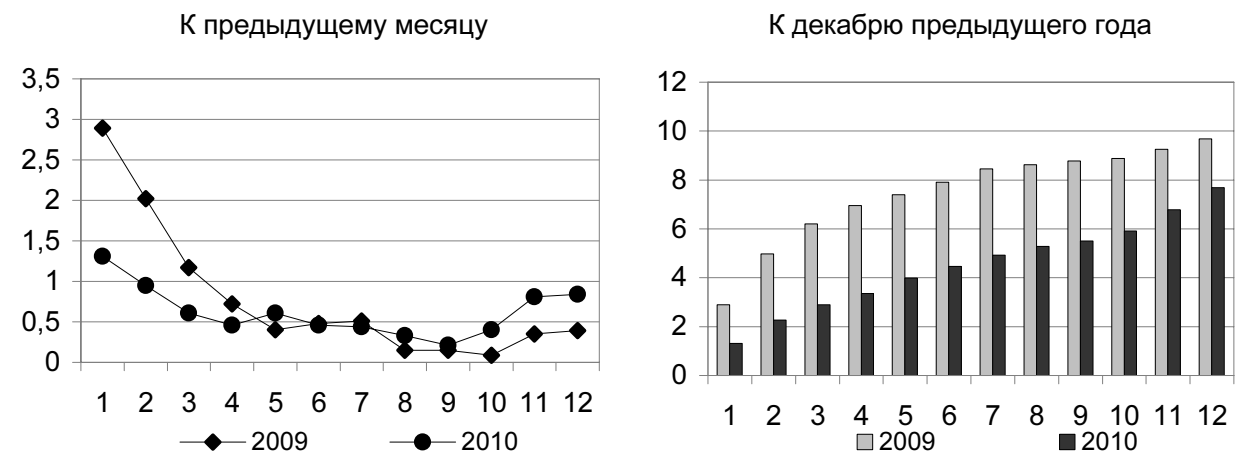

Рuc. 3. Инфляция на потребительском рынке ДФО, прирост цен, \%

В течение трех кварталов темпы инфляции снижались, достигнув наименьшего значения в сентябре. Сдерживающим механизмом роста цен явились высокие спросовые ограничения, установившиеся с середины 2009 г. Сдерживающее влияние на цены оказывало падение мировых цен на зерно и многие виды продовольствия. С сентября траектория инфляции с затухающей сменилась на растущую вследствие роста мировых и вслед за ними внутренних цен на зерно и продовольствие из-за потери части урожая 2010 г. и возросших в связи с этим инфляционных ожиданий. В декабре рост цен составил $0,84 \%$ против $0,4 \%$ в октябре.

Основной вклад в усиление инфляции внес рост цен на продовольственные товары (9,3 против 8,6\% в 2009 г.), вызванный повышением цен на отечественную сельхозпродукцию и продовольственный импорт. Засуха, в результате которой было потеряно значительное количество урожая, повлекшая за собой высокий рост цен на сельхозтовары, наиболее значительно повлияла на рост цен социально значимых продовольственных товаров, особенно на наиболее дешевые [9].

На непродовольственные товары цены в ДФО за год выросли на 5,1\% (в 2009 г. - 10,9\%). Отмечался рост цен на автомобильный бензин, табачные изделия. Удорожание сырья вследствие аномальных погодных условий обусловило усиление роста цен на одежду, текстиль, меховые изделия и иные товары легкой промышленности. Однако вследствие сохраняющегося низкого уровня спроса рост цен на большинство непродовольственных товаров существенно ниже прошлогоднего.

Рост цен на платные услуги населению составил 108,9\% (в 2009 г. $109,5 \%)$. Снижение темпов роста связано с замедлением роста тарифов на услуги, оказываемые населению организациями ЖКХ, жесткой тарифной политикой на отпускаемые для населения товары и услуги субъектов естественных монополий (рис. 4). 


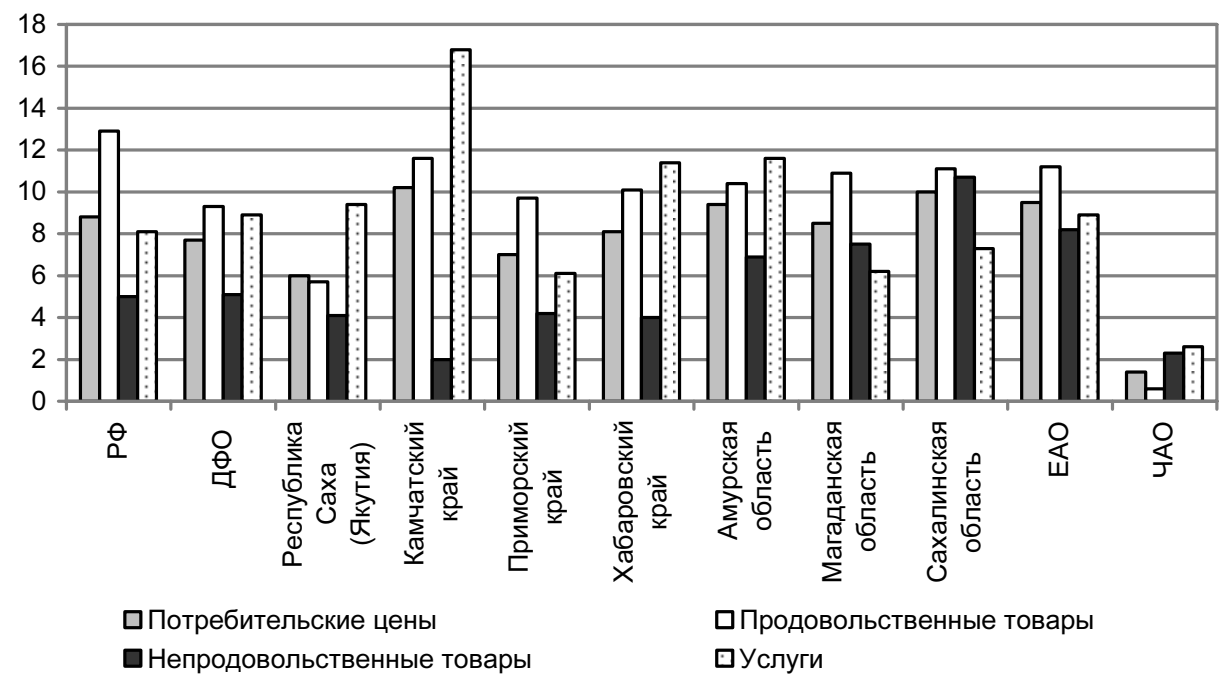

Puc. 4. Индексы потребительских цен, декабрь 2010 г., \% к декабрю 2009 г.

Сохраняются диспропорции в темпах роста между ценами производителей промышленной продукции и потребительскими ценами. В 2010 г. в ДФО цены производителей промышленных товаров выросли в среднем на 10,4\%, что на 2,7 п. п. выше роста потребительских цен. Ценовая политика в промышленности была обусловлена изменением цен на мировых рынках нефти и нефтепродуктов, цветных металлов, продукции черной металлургии, целлюлозно-бумажной промышленности. На рост цен на внутреннем рынке в значительной мере повлияли удорожание сырья и оживление спроса (табл. 8).

Таблица 8

Индекс цен производителей промышленной продукции, в \% к предыдущему периоду

\begin{tabular}{l|c|c|c|c|c}
\hline \multicolumn{1}{c|}{ Территория } & 2006 & 2007 & 2008 & 2009 & 2010 \\
\hline Российская Федерация & 110,4 & 125,1 & 93,0 & 113,9 & 116,7 \\
\hline ДФО & 108,3 & 106,9 & 116,2 & 110,9 & 110,4 \\
\hline Республика Саха (Якутия) & 103,0 & 106,9 & 123,2 & 108,2 & 103,9 \\
\hline Камчатский край & 112,3 & 103,5 & 101,7 & 125,9 & 119,0 \\
\hline Приморский край & 105,2 & 111,7 & 112,4 & 109,7 & 110,5 \\
\hline Хабаровский край & 110,7 & 109,9 & 107,1 & 116,2 & 109,1 \\
\hline Амурская область & 112,5 & 115,8 & 117,8 & 123,0 & 115,4 \\
\hline Магаданская область & 134,9 & 80,1 & 118,3 & 130,2 & 176,2 \\
\hline Сахалинская область & 105,1 & 104,4 & 118,4 & 104,8 & 104,0 \\
\hline ЕАО & 111,9 & 116,7 & 114,3 & 110,4 & 112,5 \\
\hline ЧАО & 141,0 & 109,1 & 140,9 & 111,3 & 128,3 \\
\hline
\end{tabular}

Источники: [11-13; 17]. 
№ 22011

Цены на реализованную сельскохозяйственную продукцию в 2010 г. увеличились на 6,8\%. Уровень цен производителей сельскохозяйственной продукции формировался в условиях снижения объема производства в результате аномальных погодных условий и, как следствие, повышения себестоимости продукции растениеводства и животноводства.

Рост цен в строительстве в 2010 г. составил 112,7\% и увеличился относительно 2009 г. на 5,8 п. п., что связано с оживлением спроса и инвестиционной активности.

Рост тарифов на грузовые перевозки составил 109,0\%, что на 0,9 п. п. ниже уровня 2009 г.

На сохранение высоких темпов инфляции влияли как аномальные природно-климатические условия, так и бюджетная политика государства. Мощное наращивание бюджетных расходов не могло не сказаться на ценах. Свою роль сыграли и монетарные факторы инфляции в связи с тем, что бюджетный дефицит финансировался за счет Резервного фонда и валютных интервенций в период притока капитала в начале года [7].

\section{ПРОИЗВОДСТВО ТОВАРОВ И УСЛУГ}

\section{Промышленное производство}

Топливно-энергетический комплекс. Добыча топливно-энергетических ресурсов (ТЭР) составляет основу добывающей промышленности Дальнего Востока (64,5\%). Однако большая их часть приходится на Сахалинскую область (78,7\%). В 2010 г. значительный рост добычи ТЭР наблюдался только в Республике Саха (Якутия) (181\%), а также в Камчатском крае (в 3,2 раза), что связано с началом промышленной эксплуатации газовых месторождений (ОАО «Камчатгазпром»), сосредоточенных в бассейне Охотского моря (табл. 9).

Рост нефтедобычи составил 105,2\% по сравнению с 2009 г. Это произошло главным образом за счет Республики Саха (Якутия) (180,3\%), в то время как в Сахалинской области уровень добычи стабилизировался (составляя 80,8\% от уровня добычи в ДФО). Сахалинская область также является и основным поставщиком газа среди субъектов ДФО (91,3\%). В целом за 2010 г. рост добычи газа составил 128,3\%. Также возросло производство угля (114,2\%), главным образом за счет Республики Саха (Якутия) $(156,1 \%)$. Отмечен рост нефтепереработки в Хабаровском крае на 6,6\%.

В 2010 г. продолжалось строительство газопровода Сахалин - Хабаровск - Владивосток, а также введен в эксплуатацию газопровод Соболево - Петропавловск-Камчатский в Камчатском крае.

В октябре началась прокачка технологической нефти для заполнения отвода от нефтепровода ВСТО в направлении на Китай. В ноябре на трассе 
строительства второй очереди трубопроводной системы ВСТО завершились работы по укладке трубопровода в подводную траншею через русло реки Амур протяженностью 2690 м [3].

Таблица 9

Индексы производства в топливно-энергетическом комплексе, в \% к предыдущему году

\begin{tabular}{l|c|c|c|c}
\hline \multirow{2}{*}{ Территория } & \multicolumn{2}{|c|}{$\begin{array}{c}\text { Добыча топливно- } \\
\text { энергетических ресурсов }\end{array}$} & $\begin{array}{c}\text { Производство и распределение } \\
\text { электроэнергии, газа и воды }\end{array}$ \\
\cline { 2 - 5 } & 2009 & 2010 & 2009 & 2010 \\
\hline ДФО & 112,7 & 108,9 & 102,9 & 101,8 \\
\hline Республика Саха (Якутия) & 102,3 & 181,0 & 91,8 & 100,1 \\
\hline Камчатский край & 110,1 & в 3,2 р. & 98,0 & 99,3 \\
\hline Приморский край & 122,6 & 94,7 & 95,4 & 102,6 \\
\hline Хабаровский край & 121,6 & 96,3 & 96,2 & 99,2 \\
\hline Амурская область & 112,2 & 96,2 & 108,5 & 108,3 \\
\hline Магаданская область & 93,9 & 103,3 & 100,7 & 102,5 \\
\hline Сахалинская область & 120,8 & 99,5 & 104,4 & 104,1 \\
\hline ЧАО & 69,8 & 109,0 & 100,1 & 98,0 \\
\hline
\end{tabular}

Источник: [11].

В августе 2010 г. началось строительство Нижне-Бурейской ГЭС в Амурской области. Дополнительные мощности призваны обеспечить энергией такие строящиеся объекты, как трубопровод ВСТО, Эльгинское угольное месторождение, космодром «Восточный», горно-обогатительные комбинаты Амурской области. Общий объем потребления энергии для этих объектов составит порядка 221 МВт.

Минерально-сырьевой комплекс. В 2010 г. наблюдался рост добычи руд цветных металлов $(7,3 \%)$, который обеспечивался ростом объемов в двух основных горнодобывающих территориях ДФО - Магаданской области и ЧАО (табл. 10). В последние годы рост в данной отрасли не проявляет устойчивой тенденции.

Рост выпуска главным образом связан с быстрым восстановлением после кризиса рынка драгоценных металлов, ростом цен на золото и серебро, а также с открытием новых месторождений и комбинатов.

За 9 месяцев 2010 г. в Дальневосточном федеральном округе добыто более 77 т золота. Основной объем добычи обеспечили Чукотский автономный округ - 24\%, Республика Саха (Якутия) - 21,9\%, Амурская область - 18,3\%, Магаданская область - 17,9\% и Хабаровский край - 15\%. Серебра за 9 месяцев добыто 750,9 т, из них 65,7\% приходится на месторождения Магаданской области, 21,2\% получено на месторождении Купол в Чукотском автономном 
№ 22011

округе. Благодаря возросшему содержанию серебра в рудах Хаканджинского месторождения на $67 \%$ увеличился объем добычи в Хабаровском крае, обеспечив 9,1\% добычи ДФО. Почти 4\% добычи серебра пришлось на Приморский край, где его производство выросло более чем в 1,8 раза (на 13,4 т) за счет богатых руд Майминовского месторождения [19].

Добыча руд цветных металлов

Таблица 10

\begin{tabular}{l|c|c|c}
\hline \multicolumn{1}{c|}{ Территория } & 2009 в \% к 2008 & 2010 в \% к 2009 & 2010, млн руб. \\
\hline ДФО & 97,1 & 107,3 & 125507,1 \\
\hline Республика Саха (Якутия) & 96,5 & 104,6 & 19067,0 \\
\hline Камчатский край & 86,4 & 95,0 & 5404,1 \\
\hline Приморский край & 87,5 & 81,0 & 3810,6 \\
\hline Хабаровский край & 91,6 & 99,3 & 20357,0 \\
\hline Амурская область & 116,8 & 89,9 & 22451,4 \\
\hline Магаданская область & 101,1 & 110,9 & 22685,7 \\
\hline ЧАО & 87,5 & 141,5 & 31731,3 \\
\hline
\end{tabular}

Источник: [11].

Несмотря на рост цен на медь, ее производство на Дальнем Востоке за первые девять месяцев 2010 г. сократилось почти на треть (до 913 т) по отношению к аналогичному периоду 2009 г. 51,8\% добычи пришлось на Приморский край. Здесь снижение произошло по объективным причинам - из-за падения содержания металла в руде, которая добывается попутно на месторождении вольфрама. 43,8\% добычи обеспечил Камчатский край за счет Шанучского месторождения. Снижение добычи меди в Хабаровском крае составило почти 50\%, главным образом из-за финансовых проблем ООО «Востоколово» [19].

С марта 2010 г. после двухгодичного отсутствия появился спрос на вольфрамовый концентрат на российском рынке. Кроме того, рост добычи вольфрама сопровождался вводом Лермонтовского месторождения в Приморском крае. Основным же производителем вольфрама в регионе остается ОАО «Приморский ГОК». 60\% вольфрамового концентрата компания поставила на внутренний рынок. В предыдущие годы основной спрос обеспечивал Китай, который и сейчас определяет цены на этот металл. В 2010 г. цены на вольфрамовый концентрат поднялись практически вдвое. Благодаря хорошей рыночной конъюнктуре компания смогла инвестировать доразведку Скрытого месторождения.

Также благодаря росту цен на металлы в ДФО значительно выросла добыча свинца и цинка. Олово, по мнению экспертов, все более привлекательно 
для разработки. Цена на рафинированное олово на мировом рынке неуклонно росла, превысив цены на никель. Запасы олова на российских месторождениях позволяют обеспечить объемы спроса внутреннего рынка. Однако вследствие низкого качества кондиционных руд олова и их территориального расположения конкурентоспособность дальневосточных месторождений по сравнению с зарубежными остается на крайне низком уровне. В связи с этим на правительственном уровне прорабатывается вопрос об установлении нулевой ставки НДПИ для разработки месторождений олова в ДФО.

Лесной комплекс. В 2010 г. на Дальнем Востоке отмечался рост выпуска продукции лесного комплекса (табл. 11). При этом темпы роста лесопереработки опережали темпы роста производства необработанной древесины. В структуре выпуска по обоим видам среди территорий ДФО доминировал Хабаровский край, где в отчетном периоде было сосредоточено 51,6\% валового производства необработанной древесины и 46,4\% лесоперерабатывающей промышленности. Вторым по величине лесопромышленным регионом ДФО является Приморский край (31,3 и 24,9\% соответственно).

Таблица 11

Темпы роста лесной и деревообрабатывающей промышленности ДФО в 2010 г., в \%

\begin{tabular}{l|c|c}
\hline \multicolumn{1}{c|}{ Территория } & $\begin{array}{c}\text { Древесина } \\
\text { необработанная }\end{array}$ & $\begin{array}{c}\text { Лесоматериалы } \\
\text { обработанные }\end{array}$ \\
\hline ДФО & 103,5 & 118,8 \\
\hline Республика Саха (Якутия) & 145,3 & 93,5 \\
\hline Камчатский край & 98,8 & 98,5 \\
\hline Приморский край & 114,7 & 137,6 \\
\hline Хабаровский край & 101,4 & 121,3 \\
\hline Амурская область & 95,5 & 149,4 \\
\hline Сахалинская область & 83,4 & 94,3 \\
\hline ЕАО & 71,7 & 88,1 \\
\hline
\end{tabular}

Источник: [11].

Несмотря на то, что в отчетном году лесопереработка росла опережающим темпом, она занимает лишь 10,4\% в структуре лесной промышленности Дальнего Востока, общий объем выпуска которой составил 12,6 млн м². В двух крупнейших лесопромышленных регионах - Хабаровском и Приморском краях - доля производства необработанной древесины превышает 90\%. Только в Еврейской автономной и Сахалинской областях удельный вес деревообработки находится на отметке выше $20 \%$ уровня $(23,2$ и 47,7\% соответственно). Однако на эти регионы приходится 4,5 и 3,9\% деревообрабатывающей промышленности ДФО.

В последние годы лесопромышленный комплекс подвергся серьезному 
№ 22011

воздействию в виде установления повышенных пошлин на вывоз древесины, часть крупных лесопромышленных компаний начали реализацию программ переработки. Строительство лесоперерабатывающих предприятий осуществляют компании «Амур-Форест», «Римбунан Хиджау», «Аркаим» в Хабаровском крае. Проекты по лесопереработке реализуются также в Белогорске, Тынде (Амурская область), Нижнеленинском (Еврейская автономная область).

Подавляющее большинство лесопродукции направляется на экспорт, который и позволяет существовать всему комплексу, зависящему от состояния мировых рынков. 2010 г. характеризовался повышением экспортных цен, прежде всего со стороны Китая. Дело в том, что из-за переориентации значительной части лесопромышленного комплекса России на переработку ${ }^{1}$, в Китае возник дефицит лесоматериалов, который оказались не в состоянии покрыть Северная Америка и Новая Зеландия - основные поставщики леса в Китай.

Рыбохозяйственный комплекс. В рыбной промышленности Дальнего Востока в 2010 г. была отмечена определенная стагнация. Объем рыбопереработки составил 1902,9 тыс. т, что лишь на 0,3\% выше уровня 2009 г. В структуре рыбопереработки лидирующие позиции занимают три субъекта РФ: Приморский (30,4\%), Камчатский $(30,3 \%)$ края, а также Сахалинская область (22,5\%). При этом из отмеченных регионов лишь Приморский край в 2010 г. наращивал объемы выпуска $(107,2 \%)$. Существенный рост также наблюдался в ЧАО $(169,7 \%)$, Хабаровском крае $(113,3 \%)$ и Магаданской области (106,8\%). Однако на последние три субъекта РФ приходилось лишь 16,4\% объемов рыбопереработки Дальнего Востока, что не могло компенсировать сокращения выпуска на $15,5 \%$ в Сахалинской области.

В 2010 г. Значительно увеличился экспорт рыбы и морепродуктов (табл. 12). Его объем составил 1161 тыс. т, или 1682 млн долл. США.

Таблица 12

Экспорт рыбы и морепродуктов в натуральном выражении, в \% к предыдущему году

\begin{tabular}{l|c|c|c|c}
\hline \multicolumn{1}{c|}{ Территория } & 2008 & 2009 & 2010 & Уд. вес в 2010 г., \% \\
\hline ДФО & 108,6 & 102,2 & 123,9 & 100,0 \\
\hline Камчатский край & 113,0 & 90,2 & 117,9 & 25,5 \\
\hline Приморский край & 103,2 & 117,5 & 128,8 & 35,9 \\
\hline Хабаровский край & 111,3 & 96,9 & 133,4 & 9,8 \\
\hline Магаданская область & 119,1 & 77,5 & 133,7 & 3,8 \\
\hline Сахалинская область & 114,8 & 97,3 & 119,1 & 21,3 \\
\hline ЧАО & 61,8 & 195,4 & 117,7 & 3,6 \\
\hline
\end{tabular}

Источник: [11].

${ }^{1}$ С 2007 по 2010 г. экспорт российского леса в Китай снизился с 27 млн м³ до 13 млн м³ [16]. 
Обрабатывающая промышленность. Металлургическое производство ДФО в 2010 г. демонстрировало признаки послекризисного восстановления. В Хабаровском крае рост составил 23,8\% (на фоне значительного падения выпуска в 2009 г. на 51,2\%), а в Приморском крае выпуск увеличился в 2,3 раза. Кроме того, в Амурской области был введен в эксплуатацию Олекминский горно-обогатительный комбинат, который является частью плана комплексного развития черной металлургии Дальнего Востока.

На фоне роста объемов строительства (как жилых домов, так и других объектов) наращивался выпуск строительных материалов. Производство цемента в 2010 г. выросло на 16,5\%, главным образом за счет Приморского края $(128,2 \%)$, где ведется масштабное строительство объектов к саммиту АТЭС - 2012. Производство сборных железобетонных изделий также увеличилось по всем регионам ДФО на 17,9\% (за исключением Камчатского края). Наиболее существенный рост (на 60,7\%) наблюдался в Амурской области, хотя удельный вес региона в общем выпуске отрасли по ДФО в 2010 г. составил только $11,4 \%$. Большая его часть пришлась на Хабаровский $(41,6 \%)$ и Приморский $(23,9 \%)$ края, где также отмечался рост выпуска на 18,5 и 13,6\% соответственно. Вместе с тем необходимо отметить значительное удорожание строительства, которое в Хабаровском крае составило 10,3\%, в Приморском крае - 25, в Амурской области - $11 \%$.

В машиностроительном комплексе Дальнего Востока почти 90\% производства приходится на Приморский и Хабаровский края (48,6 и 40,2\% соответственно). За 2010 г. выпуск продукции машиностроения в этих двух субъектах РФ вырос почти в 1,5 раза. Наибольший рост приходится на производство транспортных средств и оборудования (170,5\%). Кроме того, в Хабаровском крае производство машин и оборудования увеличилось на $62,5 \%$ (в Приморском крае снизилось на 17,4\%). Производство электрооборудования, электронного и оптического оборудования, напротив, снизилось в двух субъектах на 8,6\%.

В ОАО «КнААПО» в 2010 г. осуществлялось производство первых серийных самолетов SSJ 100. К настоящему времени изготовлено 7 машин, однако из-за задержек в поставках двигателей их передача заказчикам еще не состоялась. Между тем в начале февраля 2011 г. был получен сертификат МАК на этот самолет, разрешающий доступ в летный парк авиакомпаний стран $\mathrm{CH \Gamma .}$

В Благовещенске в 2010 г. началось производство промысловых судов класса «море - река». Главное направление развития - обеспечение рыболовецкими судами предприятий Сахалинской области и Камчатского края. В мае 2010 г. образовано совместное предприятие «Восток - Раффлс» по строительству в Приморском крае верфи для производства буровых платформ 
№ 22011

и морской техники для освоения шельфа. В июне образовано предприятие «Звезда - D.S.M.Е», которое будет производить суда-газовозы, нефтеналивные танкеры, нефтепромысловые сооружения для российской промышленности. В июле образовано совместное российско-корейское предприятие по строительству танкеров и газовозов.

В самом начале 2010 г. во Владивостоке состоялся запуск автомобильного производства «Соллерс - Дальний Восток». На заводе осуществляется сборка корейских внедорожников Ssang Yong, японских грузовиков Isuzu, а также российских внедорожников УАЗ. Проектом также предусмотрено создание производства автокомпонентов, которые призваны обеспечить высокую степень локализации выпускаемых автомобилей. Проектная мощность завода на 2010 г. составила 15 тыс. автомобилей. Предусмотрено увеличение выпуска до 40 тыс. автомобилей в год к 2012 г.

\section{Сельское хозяйство}

В 2010 г., несмотря на неблагоприятные погодные условия, в сельском хозяйстве ДФО отмечены положительные тенденции развития. Индекс производства составил 101,5\% к 2009 г., что на 13,4 п. п. выше аналогичного показателя по России (табл. 13).

Таблица 13

Объем продукции сельского хозяйства, в \% к предыдущему периоду

\begin{tabular}{l|c|c|c|c|c}
\hline \multicolumn{1}{c|}{ Территория } & 2006 & 2007 & 2008 & 2009 & 2010 \\
\hline Российская Федерация & 103,6 & 103,3 & 110,8 & 101,4 & 88,1 \\
\hline ДФО & 104,6 & 103,0 & 104,8 & 103,1 & 101,5 \\
\hline Республика Саха (Якутия) & 98,3 & 100,9 & 102,1 & 100,2 & 99,2 \\
\hline Камчатский край & 102,4 & 94,4 & 106,7 & 94,9 & 98,8 \\
\hline Приморский край & 106,0 & 101,3 & 109,9 & 109,2 & 101,1 \\
\hline Хабаровский край & 101,4 & 100,0 & 104,9 & 101,6 & 100,2 \\
\hline Амурская область & 114,4 & 109,3 & 105,6 & 112,0 & 101,8 \\
\hline Магаданская область & 98,7 & 104,0 & 107,4 & 104,1 & 103,1 \\
\hline Сахалинская область & 100,1 & 105,4 & 98,0 & 87,3 & 106,8 \\
\hline ЕАО & 103,1 & 106,0 & 103,2 & 92,2 & 109,4 \\
\hline ЧАО & 196,6 & 137,8 & 80,0 & 90,8 & 94,5 \\
\hline
\end{tabular}

Источники: [11-13; 17].

По предварительным данным, рост объема продукции сельского хозяйства был отмечен практически по всем (кроме Республики (Саха) Якутия, Камчатского края, Чукотского автономного округа) территориям округа. Основными производителями сельскохозяйственной продукции являют- 
ся Республика (Саха) Якутия, Приморский и Хабаровский края, Амурская область, на долю которых приходится около $80 \%$ всей продукции аграрного сектора экономики ДФО (рис. 5).

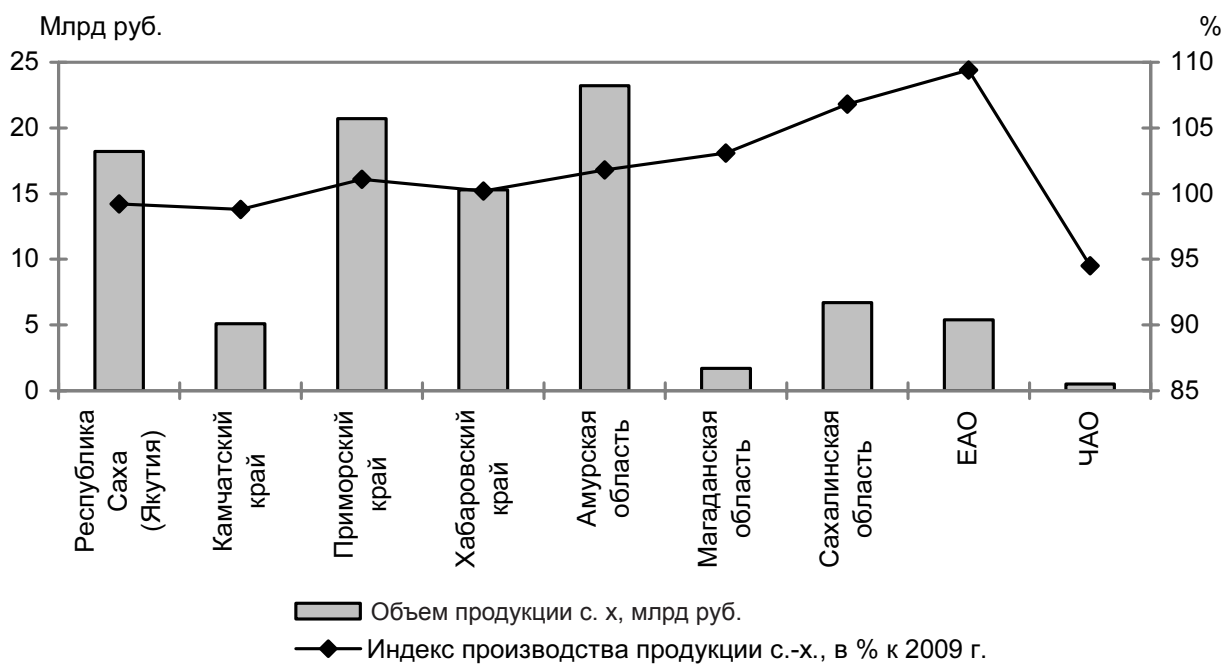

Puc. 5. Объем продукции сельского хозяйства по дальневосточным субъектам РФ в 2010 г.

В структуре сельскохозяйственного производства практически по всем территориям ДФО (кроме Республики Саха (Якутия) и Чукотского автономного округа) ведущая роль сохраняется за растениеводством, доля которого превышает 50\% в стоимости продукции. В 2010 г. рост продукции растениеводства хотя и имел положительную динамику, но темп был ниже уровня предыдущего периода (101,3 и 103,6\% в 2010 и 2009 гг. соответственно).

Неблагоприятные погодные условия привели к гибели значительной части урожая, что не позволило получить плановый валовой сбор зерновых культур. В целом по ДФО объем валового сбора зерна относительно 2009 г. сократился на 49\%, а по отдельным территориям (Амурская область, Хабаровский край, Еврейская автономная область) падение было еще значительнее и составило 60-75\% (табл. 14).

На формирование положительных темпов роста в растениеводческом комплексе оказывал влияние рост объема производства картофеля, овощей и, в большей степени, бобовых. Ведущей технической культурой на Дальнем Востоке является соя, которая приспособлена к климату Приамурья и Приморья. В 2010 г. производство сои составило 783,1 тыс. т, или на 180 тыс. т больше уровня 2009 г. при урожайности от 10 ц/га (Хабаровский край) до 12,6 ц/га (Амурская область) (табл. 15). 
Валовой сбор урожая в хозяйствах всех категорий в 2010 г.

\begin{tabular}{l|c|c|c|c|c|c}
\hline \multirow{2}{*}{ Территория } & $\begin{array}{c}\text { Зерно (в весе после } \\
\text { доработки) }\end{array}$ & \multicolumn{2}{|c}{ Картофель } & \multicolumn{2}{c}{ Овощи } \\
\cline { 2 - 7 } & тыс. т & $\begin{array}{c}\text { в \% к } \\
2009\end{array}$ & тыс. т & $\begin{array}{c}\text { в \% к } \\
2009\end{array}$ & тыс. т & $\begin{array}{c}\text { в \% к } \\
2009\end{array}$ \\
\hline Российская Федерация & 60900 & 62,7 & 21100 & 67,9 & 12100 & 90,6 \\
\hline ДФО & 296,4 & 51,0 & 1286,1 & 100,3 & 400,9 & 102,9 \\
\hline Республика Саха (Якутия) & 10,1 & 132,3 & 70,9 & 103,7 & 33,4 & 107,9 \\
\hline Камчатский край & 0,4 & в 4,4 р. & 46,1 & 90,4 & 16,2 & 99,5 \\
\hline Приморский край & 143,5 & 74,5 & 359,5 & 97,3 & 161,0 & 104,9 \\
\hline Хабаровский край & 5,6 & 32,6 & 282,6 & 97,7 & 58,3 & 97,1 \\
\hline Амурская область & 130,4 & 38,6 & 303,9 & 99,7 & 58,9 & 99,5 \\
\hline Магаданская область & - & - & 15,2 & 100,1 & 5,0 & 100,1 \\
\hline Сахалинская область & - & - & 90,7 & 126,8 & 33,7 & 101,0 \\
\hline ЕАО & 6,3 & 24,3 & 117,2 & 104,3 & 34,3 & 110,5 \\
\hline ЧАО & - & - & 0,0 & 42,9 & 0,1 & 31,6 \\
\hline
\end{tabular}

Источники: [11;13;16].

Валовой сбор и урожайность сои (в хозяйствах всех категорий)

Таблииа 15

\begin{tabular}{l|c|c|c|c}
\hline \multirow{2}{*}{\multicolumn{1}{c|}{ Территория }} & \multicolumn{2}{|c|}{ Валовой сбор, тыс. т } & \multicolumn{2}{c}{ Урожайность, ц/га } \\
\cline { 2 - 5 } & 2009 & 2010 & 2009 & 2010 \\
\hline ДФО & 603,4 & 783,1 & $\ldots$ & $\ldots$ \\
\hline Приморский край & 133,6 & 152,2 & 11,4 & 11,1 \\
\hline Хабаровский край & 11,6 & 14,7 & 10,7 & 10,0 \\
\hline Амурская область & 412,3 & 536,5 & 10,3 & 12,6 \\
\hline ЕАО & 45,9 & 79,7 & 11,0 & 12,2 \\
\hline
\end{tabular}

Источники: [10; 11].

В животноводческом комплексе ДФО рост продукции в 2010 г. составил $101,7 \%$, что незначительно ниже общероссийского уровня и показателя 2009 г. За 2010 г. хозяйствами всех категорий произведено 196 тыс. т мяса (на убой в живом весе), что составляет $107 \%$ к уровню 2009 г., отмечается рост производства яиц $(104,4 \%)$ (табл. 16). Рост производства мяса в большей степени связан не с расширением производственной базы, а с неблагоприятными погодными условиями, приведшими к сокращению объема заготовок грубых кормов и силоса. Косвенным подтверждением этого является сокращение поголовья крупного рогатого скота (95,9\% к 2009 г.), в том числе коров (94,9\%), свиней (98,5\% к 2009 г.). Сокращение поголовья коров привело к снижению производства молока. 
Таблица 16

Производство продукции животноводства в хозяйствах всех категорий в 2010 г.

\begin{tabular}{l|c|c|c|c|c|c}
\hline \multirow{2}{*}{ Территория } & \multicolumn{2}{|c|}{$\begin{array}{c}\text { Скот и птица } \\
\text { на убой (в живом } \\
\text { весе) }\end{array}$} & \multicolumn{2}{c|}{ Молоко } & \multicolumn{2}{c}{ Яйцо } \\
\cline { 2 - 8 } & тыс. т & $\begin{array}{c}\text { в \% к } \\
2009\end{array}$ & тыс. т & $\begin{array}{c}\text { в \% к } \\
2009\end{array}$ & $\begin{array}{c}\text { млн } \\
\text { штук }\end{array}$ & $\begin{array}{c}\text { в \% к } \\
2009\end{array}$ \\
\hline Российская Федерация & 10500 & 105,2 & 31900 & 97,9 & 40600 & 102,9 \\
\hline ДФО & 195,9 & 107,0 & 587,9 & 98,6 & 1173,2 & 104,4 \\
\hline Республика Саха (Якутия) & 42,5 & 109,4 & 191,1 & 96,0 & 121,2 & 97,7 \\
\hline Камчатский край & 3,7 & 104,1 & 15,8 & 106,0 & $\ldots$ & 96,4 \\
\hline Приморский край & 54,2 & 112,5 & 104,5 & 99,1 & 307,8 & 108,3 \\
\hline Хабаровский край & 32,0 & 105,2 & 52,3 & 100,0 & 299,0 & 108,4 \\
\hline Амурская область & 51,4 & 102,9 & 163,3 & 101,7 & 244,7 & 103,1 \\
\hline Магаданская область & 0,7 & 92,7 & 5,7 & 111,7 & 19,9 & 100,0 \\
\hline Сахалинская область & 4,0 & 99,7 & 28,7 & 89,3 & 108,4 & 99,4 \\
\hline ЕАО & 5,7 & 101,5 & 26,5 & 98,6 & 21,9 & 107,1 \\
\hline ЧАО & 1,6 & 95,9 & 0,1 & 106,0 & 2,9 & 82,9 \\
\hline
\end{tabular}

Источники: [11; 13; 16].

На функционирование агропромышленного комплекса Дальнего Востока негативное влияние оказывает ряд сдерживающих факторов: высокие, относительно других регионов, транспортные издержки на поставку ресурсов, необходимость использования дополнительных технологических приемов для устранения влияния неблагоприятных климатических факторов, потребность внесения повышенных доз удобрений из-за низкого естественного плодородия почв, сложившийся диспаритет цен за счет отставания роста цен на реализуемую сельскохозяйственную продукцию по сравнению с ценами на промышленные ресурсы и продовольствие, дефицит инвестиций и оборотных средств, отсутствие высококвалифицированных кадров, низкая оплата труда сельскохозяйственных работников. Решение этих и других проблем позволит сельскохозяйственному комплексу Дальнего Востока увеличить продукцию собственного производства и снизить зависимость населения округа от импорта продовольствия [20].

\section{Строительство}

В строительном комплексе ДФО в 2010 г. отмечалось оживление деловой активности (рост 6,2\%) после значительного $(9,6 \%)$ спада в предыдущий период, при этом в целом по России наблюдался спад на $0,6 \%$. Положительные тенденции развития строительного комплекса зафиксированы в большинстве дальневосточных субъектов РФ (кроме Республики (Саха) Якутия, Камчат- 
№ 22011

ского края и Амурской области), но наиболее активно строительная деятельность осуществлялась в Хабаровском и Приморском краях (рост 161 и 132,2\% соответственно), а также в Еврейской автономной области (рост в 2,1 раза).

По объему выполненных подрядных работ абсолютным лидером является Приморский край (28,2\% от общего объема), что связано с крупномасштабным строительством объектов по подготовке г. Владивостока к проведению саммита АТЭС в 2012 г. В тройку лидеров также входят Хабаровский край и Сахалинская область, доля которых по данному показателю составляет 21,7 и $17 \%$ соответственно.

В 2010 г. в целом по ДФО прирост количества вводимого жилья составил 7,6\%, что является наилучшим показателем среди федеральных округов России. Значительные объемы работ в жилищном строительстве выполнены в Приморском крае (рост 132,8\%), Сахалинской области (121,6\%), Еврейской автономной области $(107,7 \%)$ (табл. 17).

Строительный комплекс в 2010 г.

Таблица 17

\begin{tabular}{l|c|c|c|c}
\hline \multirow{2}{*}{ Территория } & \multicolumn{2}{|c|}{$\begin{array}{c}\text { Объем работ, выполненных по виду } \\
\text { деятельности «строительство» }\end{array}$} & \multicolumn{2}{|c}{ Ввод жилья } \\
\cline { 2 - 5 } & млрд руб. & в \% к 2009 & тыс. м & в \% к 2009 \\
\hline Российская Федерация & 4206,1 & 99,4 & 58100 & 97,0 \\
\hline ДФО & 308,9 & 106,2 & 1632,7 & 107,6 \\
\hline Республика Саха (Якутия) & 43,8 & 60,1 & 300,8 & 102,5 \\
\hline Камчатский край & 14,4 & 76,9 & 57,5 & 90,8 \\
\hline Приморский край & 87,2 & 132,2 & 529,7 & 132,8 \\
\hline Хабаровский край & 67,1 & 161,0 & 311,6 & 82,2 \\
\hline Амурская область & 25,8 & 87,2 & 163,9 & 109,6 \\
\hline Магаданская область & 6,6 & 100,9 & 15,9 & 101,8 \\
\hline Сахалинская область & 52,2 & 105,8 & 200,3 & 121,6 \\
\hline ЕАО & 10,8 & в 2,1 р. & 52,6 & 107,7 \\
\hline ЧАО & 1,2 & 104,0 & 0,3 & 6,6 \\
\hline
\end{tabular}

Источник: [13].

Положительная динамика жилищного строительства связана с рядом мероприятий, проводимых Правительством РФ в рамках Программы антикризисных мер. Так, было выделено финансирование на выполнение государственных обязательств по обеспечению жильем отдельных категорий граждан, на оказание поддержки молодым семьям, на обеспечение жильем всех ветеранов Великой Отечественной войны 1941-1945 гг. Важным механизмом поддержки жилищного строительства стала реализация программ 
Фонда содействия реформированию жилищно-коммунального хозяйства по расселению из аварийного и ветхого жилья, ремонту многоквартирных домов. На рост объемов ввода жилья оказывает влияние и продолжающееся улучшение условий ипотечного жилищного кредитования.

\section{Транспорт}

К позитивным тенденциям 2010 г. следует отнести оживление экономической активности в транспортном комплексе ДФО. Объем перевозки грузов всеми видами транспорта составил 222,7 млн т (рост 109,3\% после падения в 2009 г. на 6\%). Но, несмотря на положительные темпы роста, абсолютные показатели объема перевозок не превзошли уровень 2007-2008 гг. (235,1 и 241,2 млн т соответственно) (табл. 18).

Таблица 18

Динамика грузооборота, в \% к предыдущему периоду

\begin{tabular}{l|c|c|c|c|c}
\hline \multicolumn{1}{c|}{ Территория } & 2006 & 2007 & 2008 & 2009 & 2010 \\
\hline Российская Федерация & 102,2 & 102,4 & 100,7 & 89,8 & 106,9 \\
\hline ДФО & 94,1 & 104,2 & 103,7 & 102,8 & 122,7 \\
\hline Республика Саха (Якутия) & 109,2 & 110,0 & 97,0 & 97,1 & 101,6 \\
\hline Камчатский край & 97,4 & 117,3 & 125,5 & 104,5 & 130,2 \\
\hline Приморский край & 90,5 & 97,4 & 99,4 & 99,7 & 128,4 \\
\hline Хабаровский край & 95,3 & 108,1 & 104,4 & 104,0 & 122,0 \\
\hline Амурская область & 92,1 & 105,5 & 106,3 & 105,2 & 123,7 \\
\hline Магаданская область & 95,3 & 56,2 & в $3,8 \mathrm{p}$. & 120,5 & 75,5 \\
\hline Сахалинская область & 125,8 & 110,7 & 101,4 & 94,2 & 99,3 \\
\hline ЕАО & 123,9 & 146,1 & 145,1 & 186,5 & 121,9 \\
\hline ЧАО & 75,9 & 113,7 & 54,4 & 163,2 & 119,8 \\
\hline
\end{tabular}

Источники: [11-13; 17].

Увеличение объема перевозок грузов в 2010 г. отмечается практически по всем видам транспорта (кроме трубопроводного и водного), но наибольший объем перевезен железнодорожным (143,3\%), морским и воздушным $(115,5$ и $115 \%$ соответственно) видами. В структуре грузоперевозок наибольший удельный вес приходится на автомобильный $(62,3 \%)$ и железнодорожный $(27,6 \%)$ транспорт.

Грузооборот транспортного комплекса ДФО в 2010 г. составил 250,3 млрд т/км (122,7\% к уровню 2009 г.), который был обеспечен в основном ростом объемов перевезенных экспортных грузов, транспортировкой транзитной нефти, доставкой строительных изделий и металлоконструкций для строительства объектов саммита АТЭС-2012 в г. Владивостоке. 
№ 22011

Структура и направленность перевозимых грузов, значительная территориальная протяженность делают экономически безальтернативным использование железнодорожного транспорта в перевозках на дальние и сверхдальние расстояния: на долю железнодорожного транспорта ДФО приходится 83,9\% общего объема грузооборота. Прирост темпов грузооборота определялся динамикой развития железнодорожного и морского (124,5 и 123,8\% соответственно) транспорта.

В 2010 г. увеличение пассажирооборота на всех видах транспорта общего пользования составило 109,8\% к уровню 2009 г. В том числе на железнодорожном транспорте - 95,9\%, на внутреннем водном - 114,6\%, на воздушном $-123,1 \%$ на автомобильном - 105\%, на морском транспорте $-101,6 \%$.

Основной причиной снижения пассажирооборота железнодорожного транспорта является повышение тарифов на пассажирские перевозки и, как следствие, переход пассажиров на другие виды транспорта. Рост пассажирооборота на воздушном транспорте связан с проводимой авиакомпаниями гибкой тарифной политикой, а также с реализацией для жителей Дальнего Востока программы субсидирования авиаперевозок.

В 2010 г. грузооборот портов Дальнего Востока составил 118 млн т грузов (рост 128\% к 2009 г.). Из общего объема 64,4 млн т составляли сухогрузы (рост 110,2\%), наливные грузы - 53,6 млн т (рост в 1,6 раза). Увеличили грузооборот порты Ванино (на 19,2\%), Владивосток (на 12,8\%), Посьет (на 2,9\%), Ольга (на 24,1\%), Магадан (на 14,1\%). Значительное увеличение грузооборота порта Восточный (в 1,9 раза) связано с вводом в эксплуатацию перегрузочного нефтеналивного комплекса в Козьмино, портов Сахалина (в 1,4 раза) - за счет ввода в эксплуатацию перегрузочного комплекса нефти и газа в Пригородном [2].

\section{СОЦИАЛЬНАЯ СФЕРА}

\section{Доходы населения}

В 2010 г. среднедушевые номинальные денежные доходы населения в среднем по ДФО составили 20,2 тыс. руб. в месяц, увеличившись по сравнению с предыдущим годом на 10,4\%. Опережающий рост доходов населения по сравнению с ростом потребительских цен обеспечил увеличение реальных доходов к концу года в среднем по ДФО на 3,3\% (по РФ - на 3,9\%). Положительная динамика роста реальных доходов населения отмечена практически во всех (кроме Амурской области и Чукотского автономного округа) территориях Дальнего Востока. В течение 2008-2010 гг. наблюдается стабильный

\footnotetext{
${ }^{1}$ Январь - ноябрь 2010 г. в \% к январю - ноябрю 2009 г.
} 
прирост объема реальных доходов населения в среднем на 3,2-3,4\% в год, что связано с проводимой антикризисной политикой, позволившей избежать глубокого падения реальных доходов населения (табл. 19).

Таблица 19

Динамика реальных денежных доходов населения, в \% к предыдущему периоду

\begin{tabular}{l|c|c|c|c|c}
\hline \multicolumn{1}{c|}{ Территория } & 2006 & 2007 & 2008 & 2009 & 2010 \\
\hline Российская Федерация & 114,1 & 113,1 & 103,8 & 101,0 & 104,3 \\
\hline ДФО & 112,1 & 110,8 & 103,4 & 103,2 & $\ldots$ \\
\hline Республика Саха (Якутия) & 106,1 & 105,1 & 108,6 & 101,4 & 100,9 \\
\hline Камчатский край & 107,1 & 108,7 & 104,9 & 103,2 & 107,7 \\
\hline Приморский край & 115,0 & 110,6 & 104,0 & 105,0 & 106,2 \\
\hline Хабаровский край & 114,3 & 112,1 & 95,1 & 107,6 & 105,5 \\
\hline Амурская область & 110,3 & 119,6 & 111,5 & 94,2 & 98,8 \\
\hline Магаданская область & 109,1 & 106,8 & 101,0 & 101,4 & 103,5 \\
\hline Сахалинская область & 114,1 & 112,4 & 106,8 & 98,6 & 100,9 \\
\hline ЕАО & 108,3 & 105,5 & 112,0 & 104,4 & 101,3 \\
\hline ЧАО & 107,2 & 104,4 & 105,2 & 91,1 & 87,7 \\
\hline
\end{tabular}

Источники: [11-13; 17].

Среднемесячная начисленная заработная плата в 2010 г. в среднем по ДФО составляла 26,1 тыс. руб., увеличившись по сравнению с прошлым годом на 11,6\%. В 2010 г. дифференциация заработной платы между различными видами экономической деятельности не претерпела существенных структурных изменений и оставалась высокой. Максимальный размер среднемесячной заработной платы зарегистрирован в финансовом секторе Чукотского автономного округа (115,0 тыс. руб.), минимальный - в сельском хозяйстве Еврейской автономной области (9,3 тыс. руб.). Благодаря стабилизации финансового сектора и устойчивому росту цен на продукцию минерально-сырьевого и топливно-энергетического комплексов лидерами по уровню заработной платы остаются финансовая деятельность и добывающие отрасли, оплата труда в которых превышала среднемесячную заработную плату в целом по экономике ДФО в 1,7-1,8 раза. Наиболее низкий уровень среднемесячной заработной платы отмечен в сельском хозяйстве $(55 \%$ среднего по ДФО уровня).

Сохраняется тенденция пониженного уровня заработной платы в видах деятельности со значительным уровнем государственного участия (здравоохранение и предоставление социальных услуг, образование), причем, вследствие отсутствия индексации оплаты труда работников бюджетных 
№ 22011

учреждений, темпы роста заработной платы были значительно ниже, чем в других видах деятельности. Так, уровень среднемесячной начисленной заработной платы работников здравоохранения и сферы предоставления социальных услуг за январь - ноябрь 2010 г. составил к ее уровню в среднем по ДФО 75\%, к уровню в добывающих отраслях - 43,8\%, в обрабатывающих производствах - 89,3\% (в январе - ноябре 2009 г. - соответственно 78,8, 46,7 и 100,6\%). Уровень среднемесячной начисленной заработной платы работников образования составил $65,2 \%$ к среднему уровню заработной платы по ДФО, 37,7\% - к уровню в добывающих отраслях, 76,7\% - к уровню в обрабатывающих производствах (в январе - ноябре 2009 г. - соответственно $67,8,40,2$ и $85,6 \%)$.

Реальная заработная плата (с учетом изменения цен) по сравнению с 2009 г. выросла на 4,6\%, что сопоставимо со среднероссийским показателем. Рост реальной заработной платы отмечен практически во всех (кроме Сахалинской области) регионах Дальнего Востока России.

В течение года сохранялись тенденции невыплаты заработной платы. Суммарная задолженность по заработной плате на 1 января 2011 г. составила 161 млн руб. и за месяц сократилась на 25,2\%. Рост задолженности по заработной плате (в 8,2 раза) отмечается лишь в Камчатском крае, в остальных регионах Дальнего Востока снижение составило 20-75\%. В общем объеме просроченной задолженности по заработной плате почти $40 \%$ приходится на транспорт, 24\% - на производство и распределение электроэнергии, газа и воды, 17,8\% - на обрабатывающие производства. Весь объем задолженности был сформирован в результате отсутствия у предприятий и организаций собственных средств.

\section{Демографическая ситуация}

На 1 января 2010 г. численность постоянного населения ДФО составила 6440,4 тыс. человек и по сравнению с 2009 г. уменьшилась на 19,7 тыс. человек, или на 0,3\%. Естественная убыль населения в январе - ноябре 2010 г. достигла 3433 человека, что в 2,3 раза выше по сравнению с соответствующим периодом 2009 г. Естественный прирост сохраняется лишь в Республике Саха (Якутия) и Чукотском автономном округе, в остальных субъектах РФ высока естественная убыль населения, и особенно это характерно для Приморского края, Сахалинской и Магаданской областей, Хабаровского края (табл. 20).

В январе - ноябре 2010 г. общий коэффициент рождаемости (число родившихся на 1000 человек населения) составил 12,9 (по РФ - 12,6), сохранившись на уровне 2009 г. На фоне стагнации рождаемости в 2010 г. был отмечен рост уровня смертности населения, который характеризует здоровье 
населения и, в конечном счете, социальный статус общества. Общий коэффициент смертности населения (число умерших на 1000 человек населения) в январе - ноябре 2010 г. составил 13,5 против 13,2 в 2009 г. Показатели смертности на Дальнем Востоке традиционно выглядят лучше среднероссийских, благодаря более молодой структуре населения, которая в меньшей степени подвержена естественной убыли. В 2010 г. эти тенденции сохранились, и коэффициент смертности по ДФО на 5,6\% был ниже среднероссийского показателя.

Таблица 20

Динамика общих коэффициентов рождаемости, смертности и естественного прироста (убыли) населения в РФ и ДФО

\begin{tabular}{|c|c|c|c|c|c|c|}
\hline \multirow[t]{2}{*}{ Территория } & \multicolumn{2}{|c|}{$\begin{array}{l}\text { Коэффициент } \\
\text { рождаемости }\end{array}$} & \multicolumn{2}{|c|}{$\begin{array}{c}\text { Коэффициент } \\
\text { смертности }\end{array}$} & \multicolumn{2}{|c|}{$\begin{array}{c}\text { Коэффициент } \\
\text { естественного } \\
\text { прироста (убыли) } \\
\text { населения }\end{array}$} \\
\hline & 2009 & 2010 & 2009 & 2010 & 2009 & 2010 \\
\hline Российская Федерация & 12,4 & 12,6 & 14,2 & 14,3 & $-1,8$ & $-1,7$ \\
\hline ДФО & 12,9 & 12,9 & 13,2 & 13,5 & $-0,3$ & $-0,6$ \\
\hline Республика Саха (Якутия) & 16,6 & 16,9 & 9,9 & 9,9 & $+6,7$ & $+7,0$ \\
\hline Камчатский край & 11,9 & 11,3 & 11,7 & 12,0 & $+0,2$ & $-0,7$ \\
\hline Приморский край & 11,7 & 11,8 & 13,7 & 14,2 & $-2,0$ & $-2,4$ \\
\hline Хабаровский край & 12,5 & 12,4 & 13,5 & 14,1 & $-1,0$ & $-1,7$ \\
\hline Амурская область & 13,2 & 13,4 & 14,6 & 14,7 & $-1,4$ & $-1,3$ \\
\hline Магаданская область & 12,0 & 11,1 & 13,0 & 12,9 & $-1,0$ & $-1,8$ \\
\hline Сахалинская область & 12,1 & 11,8 & 14,4 & 14,5 & $-2,3$ & $-2,7$ \\
\hline EAO & 13,2 & 13,1 & 14,7 & 14,6 & $-1,5$ & $-1,5$ \\
\hline ЧАО & 14,2 & 15,0 & 12,5 & 14,5 & $+1,7$ & 0,5 \\
\hline
\end{tabular}

Источники: [11;14].

Сальдо миграции в 2010 г. в целом по ДФО было отрицательным

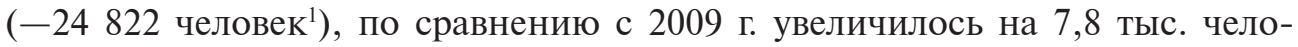
век. Результативность миграции в 2010 г. составила 1,3, т.е. на 10 человек, прибывших в ДФО, приходится 13 человек, покидающих регион. В 2010 г. увеличились объемы миграции по прибытию, и, соответственно, увеличилась возвратная миграция. Наибольший абсолютный миграционный отток населения был из Республики Саха (Якутия) (6479 человек), Приморского края (6312 человек), Амурской и Сахалинской областей (3326 и 2846 человек соответственно) (табл. 21).

\footnotetext{
1 Январь - ноябрь 2010 г.
} 
Таблица 21

Общие итоги миграции населения по территориям ДФО (январь - ноябрь), чел.

\begin{tabular}{l|c|c|c|c|c|c}
\hline \multirow{2}{*}{\multicolumn{1}{c|}{ Территория }} & \multicolumn{2}{|c|}{ Число прибывших } & \multicolumn{2}{c}{ Число выбывших } & \multicolumn{2}{c}{ Сальдо миграции } \\
\cline { 2 - 8 } & 2009 & 2010 & 2009 & 2010 & 2009 & 2010 \\
\hline ДФО & 85199 & 88708 & 102167 & 113530 & -16968 & -24822 \\
\hline Республика Саха (Якутия) & 13836 & 13379 & 20403 & 19858 & -6567 & -6479 \\
\hline Камчатский край & 4671 & 6071 & 5999 & 6442 & -1328 & -371 \\
\hline Приморский край & 22875 & 22490 & 24578 & 28802 & -1703 & -6312 \\
\hline Хабаровский край & 17989 & 20009 & 18353 & 22434 & -364 & -2425 \\
\hline Амурская область & 13017 & 14012 & 15328 & 17338 & -2311 & -3326 \\
\hline Магаданская область & 2943 & 2678 & 4408 & 4425 & -1465 & -1747 \\
\hline Сахалинская область & 6296 & 6060 & 8583 & 8906 & -2287 & -2846 \\
\hline ЕАО & 2852 & 3209 & 2867 & 3752 & -15 & -543 \\
\hline ЧАО & 720 & 800 & 1648 & 1573 & -928 & -773 \\
\hline
\end{tabular}

Источники: [11; 14; 15].

В результате естественной убыли населения и миграционного оттока деформируется возрастная структура населения, сокращается численность экономически активного населения, что в совокупности является факторами риска для социально-экономического развития региона и национальной безопасности России на Востоке [8].

\section{Рынок труда}

Ситуация на рынке труда к концу 2010 г. складывалась значительно лучше, чем ожидалось в начале года. На конец декабря численность безработных, определяемых по методологии МОТ, на основании обследования по проблемам занятости, составила в ДФО 307 тыс. человек, снизившись по сравнению с 2009 г. на 7,9\%. Численность безработных граждан, зарегистрированных в органах службы занятости населения, сократилась на 10,1\%.

Число вакантных рабочих мест в органах службы занятости населения на конец декабря 2010 г. составила 94,6 тыс. человек, увеличившись относительно декабря 2009 г. на 21,5\%. Наибольшую потребность в кадрах испытывают Приморский край (47,4 тыс. человек), Хабаровский край (15,1 тыс. человек), Амурская область (11,8 тыс. человек).

Однако коэффициент напряженности в расчете на 100 заявленных вакансий в конце 2010 г. в целом по ДФО составил 102,7 человека и снизился на 36,9\%. Высока напряженность на рынке труда в Республике (Саха) Якутия, где на 100 заявленных вакансий претендуют 259,4 человека, в Хабаровском крае (178,5 человека), Чукотском автономном округе (168,5 человека). 
Средняя продолжительность поиска работы безработными составляет в среднем 6,6-8 месяцев. Безработица в значительной степени является застойной: 25-37\% из общего числа безработных по территориям Дальнего Востока находились в ситуации застойной безработицы (искали работу 12 месяцев и более) (табл. 22).

Таблица 22

Численность безработных в 2010 г. (по данным обследований населения по проблемам занятости)

\begin{tabular}{l|c|c|c|c}
\hline \multicolumn{1}{|c|}{ Территория } & $\begin{array}{c}\text { Без- } \\
\text { работные, } \\
\text { тыс. чел. }\end{array}$ & $\begin{array}{c}2010 \text { в \% } \\
\text { к 2009 }\end{array}$ & $\begin{array}{c}\text { Среднее время } \\
\text { поиска работы } \\
\text { безработными, } \\
\text { месяцев }\end{array}$ & $\begin{array}{r}\text { Доля в общей } \\
\text { численности } \\
\text { безработных, } \\
\text { ищущих работу } \\
\text { 12 месяцев и более, \% }\end{array}$ \\
\hline ДФО & 307,0 & 92,1 & 7,2 & 28,6 \\
\hline Республика Саха (Якутия) & 43,4 & 99,6 & 7,1 & 28,0 \\
\hline Камчатский край & 14,5 & 91,0 & 6,8 & 25,7 \\
\hline Приморский край & 104,8 & 97,4 & 6,7 & 24,8 \\
\hline Хабаровский край & 70,3 & 86,7 & 8,0 & 29,8 \\
\hline Амурская область & 30,9 & 77,3 & 7,1 & 37,3 \\
\hline Магаданская область & 5,9 & 86,0 & 8,0 & 23,1 \\
\hline Сахалинская область & 27,3 & 93,0 & 6,6 & 31,3 \\
\hline ЕАО & 8,5 & 111,9 & 7,7 & 25,1 \\
\hline ЧАО & 1,3 & 91,1 & 7,8 & \\
\hline
\end{tabular}

Источник: [13].

В настоящее время происходит увеличение размеров структурной безработицы. Острую нехватку квалифицированных кадров испытывают такие отрасли Дальнего Востока, как машиностроение, судостроение, сельское хозяйство.

В 2010 г. из федерального бюджета было выделено 39,5 млрд руб. на предоставление субсидий бюджетам субъектов РФ на снижение напряженности на рынке труда в рамках соответствующих региональных программ [6].

\section{ВНЕШНЕЭКОНОМИЧЕСКОЕ СОТРУДНИЧЕСТВО}

\section{Иностранные инвестиции}

В 2010 г. объем иностранных инвестиций в регионе сократился до 7309,5 млн долл. США (86,6\% к уровню 2009 г. $)^{1}$ (рис. б).

${ }^{1}$ Объем иностранных инвестиций приведен с учетом рублевых поступлений, пересчитанных в доллары США. 


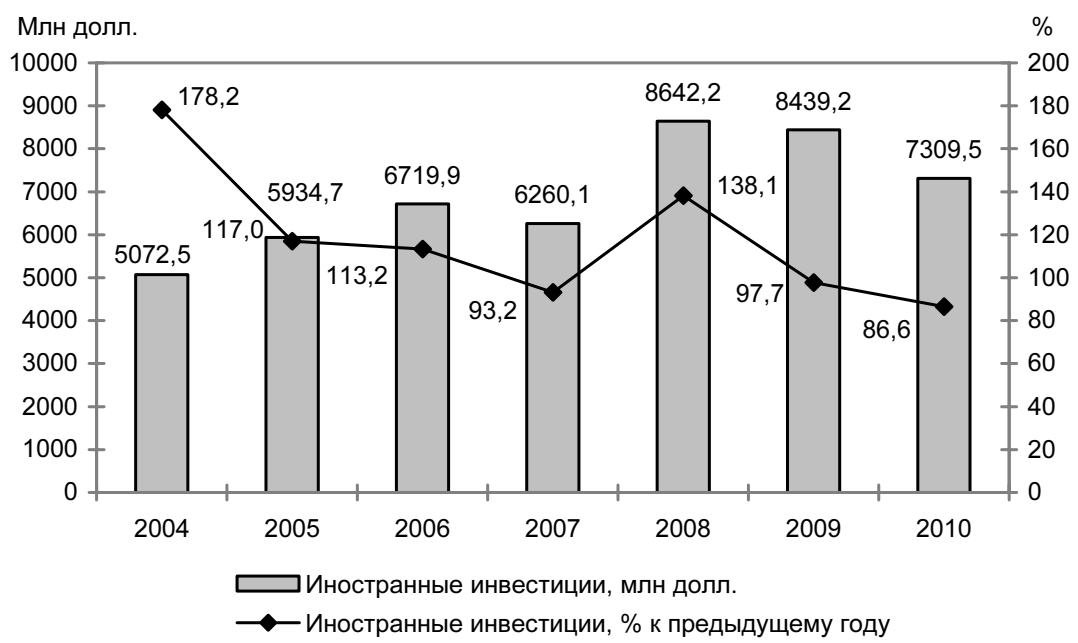

Puc. 6. Динамика поступления иностранных инвестиций на Дальний Восток России в 2004-2010 гг.

Как и в 2009 г., только 16,1\% всех поступивших иностранных инвестиций относились к прямым инвестициям, а основной их объем $(83,33 \%)$ был осуществлен в форме прочих инвестиций (торговые кредиты, прочие кредиты и т. п.). При этом было отмечено обвальное падение (в 7 раз) притока портфельных инвестиций до уровня в 48,2 млн долл., которые поступали только в Приморский край и Республику Саха (Якутия) (табл. 23). Как и в предыдущие годы, подавляющая часть как всех иностранных, так и прямых иностранных инвестиций (ПИИ), поступающих на Дальний Восток, осуществлялась в Сахалинской области $(68,19 \%)$.

Кроме того, прочие иностранные инвестиции (в основном осуществляемые на кредитной основе) в 2010 г. также были направлены в основном в Сахалинскую область (68,73\% от их общего объема), Республику Саха (Якутия) $(21,85 \%)$, Хабаровский край $(8,89 \%)$ и Амурскую область $(2,79 \%)$.

В структуре иностранных инвестиций наибольший удельный вес $(83,33 \%)$ занимают прочие инвестиции, осуществляемые на возвратной основе (торговые кредиты и кредиты международных финансовых организаций). На долю прямых инвестиций (в основном это взносы в уставный фонд, кредиты, прочие вложения) приходится 16,01\%, портфельных - 0,66\%.

Наиболее привлекательным для иностранного капитала видом экономической деятельности в ДФО является добыча полезных ископаемых 6,56 млрд долл. (89,79\% от всех поступлений). Это направление является основным для Республики Саха (Якутия), Сахалинской и Амурской областей, Еврейской автономной области, Чукотского автономного округа. 
Таблииа 23

Структура иностранных инвестиций по территориям Дальнего Востока в 2010 г.

\begin{tabular}{|c|c|c|c|c|c|c|c|c|c|}
\hline \multirow{3}{*}{\multicolumn{2}{|c|}{ Территория }} & \multirow{2}{*}{\multicolumn{2}{|c|}{ Всего }} & \multicolumn{6}{|c|}{ В том числе } \\
\hline & & & & \multicolumn{2}{|c|}{ прямые } & \multicolumn{2}{|c|}{ портфельные } & \multicolumn{2}{|c|}{ прочие } \\
\hline & & тыс. долл. & $\%$ & тыс. долл. & $\%$ & тыс. долл. & $\%$ & тыс. долл. & $\%$ \\
\hline \multirow{2}{*}{$\begin{array}{c}\text { Даль- } \\
\text { ний } \\
\text { Вос- } \\
\text { ток }\end{array}$} & 2009 & 8439278,70 & & 1499659,80 & & 343478,64 & & 6596140,2 & \\
\hline & 2010 & 7309521,07 & 100 & 1170320,87 & 100 & 48247,40 & 100 & 6090952,8 & 100 \\
\hline \multicolumn{2}{|c|}{$\begin{array}{l}\text { Республика } \\
\text { Саха (Яку- } \\
\text { тия) }\end{array}$} & 1336637,4 & 18,29 & 2479,4 & 0,21 & 3118,8 & 6,46 & 1331039,2 & 21,85 \\
\hline \multicolumn{2}{|c|}{$\begin{array}{l}\text { Примор- } \\
\text { ский край }\end{array}$} & 114271,4 & 1,56 & 51504,3 & 4,4 & 45127,8 & 93,53 & 17639,3 & 0,29 \\
\hline \multicolumn{2}{|c|}{$\begin{array}{l}\text { Хабаров- } \\
\text { ский край }\end{array}$} & 418652,3 & 5,73 & 59592,8 & 5,09 & 0,1 & 0,00 & 359059,4 & 5,89 \\
\hline \multicolumn{2}{|c|}{$\begin{array}{l}\text { Амурская } \\
\text { область }\end{array}$} & 380123,9 & 5,2 & 210451,8 & 17,98 & - & - & 169672,1 & 2,79 \\
\hline \multicolumn{2}{|c|}{$\begin{array}{l}\text { Камчат- } \\
\text { ский край }\end{array}$} & 33429,07 & 0,46 & 7641,47 & 0,65 & 0,5 & 0,00 & 25787,1 & 0,42 \\
\hline \multicolumn{2}{|c|}{$\begin{array}{l}\text { Магадан- } \\
\text { ская об- } \\
\text { ласть }\end{array}$} & 297,2 & 0,004 & 0,8 & 0,00 & - & - & 296,4 & 0,00 \\
\hline \multicolumn{2}{|c|}{$\begin{array}{l}\text { Сахалин- } \\
\text { ская об- } \\
\text { ласть }\end{array}$} & 4984477,5 & 68,19 & 798022,9 & 68,19 & 0,2 & 0,00 & 4186454,4 & 68,73 \\
\hline \multicolumn{2}{|l|}{ EAO } & 16160,7 & 0,22 & 16160,7 & 1,38 & - & - & - & - \\
\hline \multicolumn{2}{|l|}{ ЧАО } & 25471,6 & 0,35 & 24466,7 & 2,09 & - & - & 1004,9 & 0,02 \\
\hline
\end{tabular}

Источники: [11-13; 17].

Динамика привлечения иностранных инвестиций на российском Дальнем Востоке уже длительный период определяется реализацией ряда проектов, связанных с добычей полезных ископаемых (минеральных ресурсов) на его территории. Доля иностранных инвестиций, направляемых в добычу полезных ископаемых, в 2010 г. только немного снизилась до уровня в 89,79\% от всех вложений. При этом значительные вложения в 2010 г. были зафиксированы в таких видах экономической деятельности, как обрабатывающие производства $(4,68 \%)$ и операции с недвижимым имуществом, арендой и предоставлением услуг $(3,03 \%)$, из которых подавляющая часть была направлена на геологоразведочные, геофизические и геохимические работы в области изучения недр (табл. 24). 
Структура поступления иностранных инвестиций на Дальнем Востоке по видам экономической деятельности

\begin{tabular}{l|c|c|c|c}
\hline \multicolumn{1}{c|}{ Вид экономической деятельности } & \multicolumn{2}{|c|}{2009} & \multicolumn{2}{c}{2010} \\
\cline { 2 - 5 } & тыс. долл. & $\%$ & тыс. долл. & $\%$ \\
\hline Всего по экономике & 8439278,7 & 100 & 7309521,07 & 100 \\
\hline $\begin{array}{l}\text { Сельское хозяйство, охота и предоставление услуг } \\
\text { в этих областя }\end{array}$ & 44491,4 & 0,53 & 40135,6 & 0,55 \\
\hline Рыболовство, рыбоводство и лесное хозяйство & 22158,3 & 0,26 & 15809,8 & 0,22 \\
\hline Добыча полезных ископаемых & 7772370,4 & 92,1 & 6563212 & 89,79 \\
\hline Обрабатывающие производства & 193499,6 & 2,29 & 342137,6 & 4,68 \\
\hline Строительство & 38378,3 & 0,45 & 19147,9 & 0,26 \\
\hline $\begin{array}{l}\text { Оптовая и розничная торговля; ремонт автотран- } \\
\text { спортных средств, мотоциклов, бытовых изделий } \\
\text { и предметов личного пользования }\end{array}$ & 57837 & 0,69 & 29663,6 & 0,41 \\
\hline Гостиницы и рестораны & 190 & 0,00 & 918,7 & 0,01 \\
\hline Транспорт и связь & 37188,5 & 0,44 & 75523,9 & 1,03 \\
\hline Финансовая деятельность & 0,3 & 0,00 & 1330 & 0,02 \\
\hline $\begin{array}{l}\text { Операции с недвижимым имуществом, аренда и } \\
\text { предоставление услуг }\end{array}$ & 273159,6 & 3,24 & 221640,97 & 3,03 \\
\hline Образование & - & - & 0,4 & 0,00 \\
\hline $\begin{array}{l}\text { Производство и распределение электроэнергии, } \\
\text { газа и воды }\end{array}$ & - & - & 0,53 & 0,00 \\
\hline $\begin{array}{l}\text { Здравоохранение и предоставление социальных } \\
\text { услуг }\end{array}$ & 1,1 & 0,0 & - & - \\
\hline $\begin{array}{l}\text { Предоставление прочих коммунальных, социаль- } \\
\text { ных и персональных услуг }\end{array}$ & 4,4 & 0,0 & - & - \\
\hline
\end{tabular}

Источники: [11-13; 17].

Сахалинская область, благодаря реализации на ее территории крупных проектов, связанных с разработкой нефтегазовых шельфовых месторождений в 2010 г., продолжает сохранять лидирующие позиции по привлечению иностранных инвестиций среди дальневосточных субъектов РФ. На нее пришлось 68,19\% общего объема иностранных инвестиций и объемов прямых инвестиций в экономику Дальнего Востока. При этом в целом объем иностранных инвестиций в Сахалинской области в 2010 г. снизился на 13,5\% по сравнению с 2009 г. и составил 4,984 млрд долл.

Вторым субъектом РФ по уровню привлекательности для зарубежного капитала в 2010 г. (с объемом инвестиций в 1336,6 млн долл., или 18,29\% общих объемов на Дальнем Востоке) стала Республика Саха (Якутия). При этом в 2010 г. поступление иностранных инвестиций в экономику Республики Саха (Якутия) увеличилось почти на $20 \%$. 
Позиции лидирующих стран-инвесторов экономики Дальнего Востока в 2010 г. несколько изменились (табл. 25).

Таблица 25

Иностранные инвестиции по лидирующим странам-инвесторам в 2009-2010 гг.

\begin{tabular}{l|c|c|c|c}
\hline \multirow{2}{*}{ Страна } & \multicolumn{2}{|c|}{2009} & \multicolumn{2}{c}{2010} \\
\cline { 2 - 5 } & тыс. долл. & $\%$ & тыс. долл. & $\%$ \\
\hline Дальний Восток, всего & 8439278,7 & 100 & 7309521,07 & 100 \\
\hline Нидерланды & 1915417,1 & 22,70 & 2912806,1 & 39,85 \\
\hline Люксембург & 735881,4 & 8,72 & 1300000 & 17,79 \\
\hline Япония & 2661406,1 & 31,54 & 809517,3 & 11,07 \\
\hline Багамские острова & 620905,9 & 7,36 & 786296,8 & 10,76 \\
\hline Кипр & 910403,6 & 10,79 & 540149,2 & 7,39 \\
\hline Индия & 395847,6 & 4,69 & 506980,5 & 6,94 \\
\hline Великобритания & 905044,8 & 10,72 & 185066,7 & 2,53 \\
\hline Канада & 20676 & 0,24 & 88150,87 & 1,21 \\
\hline Китай & 45157,3 & 0,54 & 45937,77 & 0,63 \\
\hline Республика Корея & 82764,9 & 0,98 & 42696,7 & 0,58 \\
\hline
\end{tabular}

Источники: [11-13; 17].

Основные страны-инвесторы, осуществляющие значительные вложения в Дальневосточный федеральный округ в 2010 г.: Нидерланды - 2912,8 млндолл., Люксембург - 1300 млн долл., Япония - 809,5 млн долл., Багамские острова - 786,3 млн долл., Кипр - 540,1 млн долл., Индия - 506,9 млн долл., Великобритания - 185 млн долл.

\section{Внешняя торговля}

Формирование объемов внешней торговли в 2010 г. происходило на фоне заметного укрепления позиций рубля по отношению к основным иностранным валютам (индекс реального эффективного курса рубля по сравнению с 2009 г. составил 9,6\%), роста реальных денежных доходов населения $\left(103,3 \%{ }^{1}\right)$ и реальной начисленной заработной платы (104,6\%). Наряду с этим определенную роль сыграли положительные сдвиги в динамике внешнего спроса на рынках сопредельных стран и рост цен на традиционную продукцию дальневосточного экспорта.

Внешнеторговый оборот ДФО с зарубежными странами в 2010 г. увеличился по сравнению с 2009 г. с 15,4 до 23,5 млрд долл. ${ }^{2}$, в том числе экспорт -

1 Январь - ноябрь 2010 г. к январю - ноябрю 2009 г.

2 По данным Дальневосточного таможенного управления ФТС РФ (не включая экспорт продукции алмазного комплекса). 
с 10,7 до 15,9 млрд долл. (162,2\%), импорт - с 4,7 до 7,6 млрд долл. (148,2\%). Активное сальдо торгового баланса региона увеличилось на $37,4 \%$ и составило 8,3 млрд долл.

Увеличение объемов экспорта обеспечено, главным образом, за счет поставок продукции ТЭК (с 7,4 до 11,8 млрд долл.), в результате чего удельный вес данной продукции в товарной структуре дальневосточного экспорта увеличился до 74,3\% (против 69\% в 2009 г.). Увеличение объемов экспорта, хотя и не столь значительное, происходило и по таким товарным позициям, как рыба и морепродукты (на 295,9 млн долл.) и лесотовары (на 161,1 млн долл.). В наименьшей степени - по металлам и изделиям из них, машинотехнической продукции (табл. 26).

Товарная структура экспорта Дальнего Востока *

Таблица 26

\begin{tabular}{l|c|c|c|c}
\hline \multirow{2}{*}{ Товарная группа } & \multicolumn{2}{|c|}{2009} & \multicolumn{2}{c}{2010} \\
\cline { 2 - 5 } & млн долл. & $\%$ & млн долл. & $\%$ \\
\hline Экспорт, всего & 10724,8 & 100,0 & 15896,4 & 100,0 \\
\hline $\begin{array}{l}\text { Машины, оборудование, транспортные } \\
\text { средства }\end{array}$ & 250,6 & 2,3 & 339,5 & 2,1 \\
\hline Топливо, минеральное сырье, металлы & 7852,6 & 73,2 & 12469,1 & 78,4 \\
\hline \multicolumn{1}{|c|}{ продукция ТЭК } & 7394,9 & 69,0 & 11806,3 & 74,3 \\
\hline \multicolumn{1}{c|}{ металлы и изделия из них } & 345,0 & 3,2 & 497,9 & 3,1 \\
\hline Химические товары & 58,3 & 0,5 & 50,0 & 0,3 \\
\hline Сырье и продукты его переработки & 892,7 & 8,3 & 1053,7 & 6,6 \\
\hline \multicolumn{1}{|c|}{ лесотовары } & 891,8 & 8,3 & 1052,9 & 6,6 \\
\hline Пищевкусовые товары & 1658,7 & 15,5 & 1981,2 & 12,5 \\
\hline \multicolumn{1}{|c|}{ рыбопродукция } & 1608,3 & 15,0 & 1904,2 & 12,0 \\
\hline Промышленные товары народного & 1,7 & 0,0 & 1,0 & 0,0 \\
\hline потребления & 10,2 & 0,2 & 1,9 & 0,1 \\
\hline Прочие & & & & \\
\hline
\end{tabular}

Примечание. * Без учета экспорта услуг, поставок бункерного топлива.

Источник: составлено на основе данных таможенной статистики (не включая экспорт продукции алмазного комплекса, драгоценных металлов и изделий из них).

Среди вышеуказанных товарных позиций наиболее высокую долю в структуре экспорта занимала рыбопродукция (12\%). В 2010 г. на внешний рынок из региона было вывезено свыше 1 млн т рыбы и морепродуктов. В экспорте рыбопродукции традиционно доминировала рыба мороженая (91\% от общего объема), в товарной структуре которой преобладали минтай, печень, икра и молоки мороженые, сельдь, треска. 
Свыше 60\% дальневосточного экспорта рыбопродукции было направлено на рынок Китая, 33\% - на рынок Республики Корея. Объемы экспорта водных биологических ресурсов в Японию не превышали 5\% (главным образом ценные объекты промысла: краб, креветка, моллюски, морской еж, икра лососевая, нерка).

Положительная динамика объемов регионального импорта в 2010 г., в отличие от экспорта, обеспечивалась существенным ростом объемов закупок промышленных товаров народного потребления (в 2,1 раза) и продукции машиностроения (на 61,6\%), а также металлов и изделий из них (на 50,4\%). В товарной структуре импорта заметно увеличилась доля товаров народного потребления (с 22,5 до 29,4\%) (табл. 27).

Таблица 27

Товарная структура импорта Дальнего Востока *

\begin{tabular}{|c|c|c|c|c|}
\hline \multirow{2}{*}{ Товарная группа } & \multicolumn{2}{|c|}{2009} & \multicolumn{2}{|c|}{2010} \\
\hline & млн долл. & $\%$ & млн долл. & $\%$ \\
\hline Импорт, всего & 4684,7 & 100,0 & 7598,9 & 100,0 \\
\hline $\begin{array}{l}\text { Машины, оборудование, транспорт- } \\
\text { ные средства }\end{array}$ & 1784,0 & 38,1 & 2882,0 & 37,9 \\
\hline Топливо, минеральное сырье, металлы & 540,7 & 11,5 & 893,1 & 11,8 \\
\hline Химические товары & 377,9 & 8,1 & 549,2 & 7,2 \\
\hline $\begin{array}{l}\text { Древесина и целлюлозно-бумажные } \\
\text { изделия }\end{array}$ & 87,4 & 1,9 & 124,0 & 1,6 \\
\hline Товары народного потребления & 1893,8 & 40,4 & 3145,4 & 41,4 \\
\hline пищевкусовые товары & 840,8 & 17,9 & 912,2 & 12,0 \\
\hline $\begin{array}{l}\text { промышленные товары народного } \\
\text { потребления }\end{array}$ & 1053,0 & 22,5 & 2233,2 & 29,4 \\
\hline Прочие & 0,9 & 0,0 & 5,2 & 0,1 \\
\hline
\end{tabular}

Примечание. * Без учета импорта услуг, поставок бункерного топлива. Источник: составлено на основе данных таможенной статистики.

В целом, несмотря на произошедшие изменения в товарных структурах дальневосточного экспорта и импорта, во внешней торговле региона продолжала иметь место существенная асимметричность экспортно-импортных потоков в части их товарного наполнения.

Среди дальневосточных субъектов РФ наиболее высокие показатели темпов прироста объемов торговли в 2010 г. по сравнению с предыдущим периодом были достигнуты в Республике Саха (Якутия) - 81\%, Приморском крае - 68,4\%, Еврейской автономной области - 57,6\% и Сахалинской области $-49,8 \%$. 
№ 22011

Свыше 90\% внешнеторгового оборота региона приходилось на Сахалинскую область, Приморский и Хабаровский края. К числу наименее вовлеченных во внешнеторговое сотрудничество субъектов ДФО относились Еврейская автономная область (0,2\% в объеме товарооборота ДФО) и Чукотский автономный округ $(0,7 \%)$ (табл. 28).

Территориальная структура внешней торговли

Таблица 28 Дальнего Востока, млн долл., \% *

\begin{tabular}{l|c|c|c|c|c|c}
\hline \multirow{2}{*}{ Территория } & \multicolumn{3}{|c|}{2009} & \multicolumn{3}{c}{2010} \\
\cline { 2 - 7 } & экспорт & импорт & оборот & экспорт & импорт & оборот \\
\hline \multirow{2}{*}{ ДФО } & 10724,8 & 4684,7 & 15409,5 & 15896,4 & 7598,9 & 23495,3 \\
& 100,0 & 100,0 & 100,0 & 100,0 & 100,0 & 100,0 \\
\hline \multirow{2}{*}{ Республика Саха (Якутия) } & 299,8 & 63,4 & 363,2 & 590,6 & 66,8 & 657,4 \\
& 2,8 & 1,4 & 2,4 & 3,7 & 0,9 & 2,8 \\
\hline \multirow{2}{*}{ Камчатский край } & 540,4 & 66,8 & 607,2 & 630,2 & 67,1 & 697,3 \\
\hline \multirow{2}{*}{ Приморский край } & 5,0 & 1,4 & 3,9 & 4,0 & 0,9 & 3,0 \\
\hline \multirow{2}{*}{ Хабаровский край } & 1061,0 & 2734,3 & 3795,3 & 1402,0 & 4987,8 & 6389,8 \\
\hline \multirow{2}{*}{ Амурская область } & 9,9 & 58,4 & 24,6 & 8,8 & 65,6 & 27,2 \\
\hline \multirow{2}{*}{ Сахалинская область } & 973,6 & 499,3 & 1472,9 & 1219,3 & 926,7 & 2146,0 \\
& 9,1 & 10,7 & 9,6 & 7,7 & 12,2 & 9,1 \\
\hline \multirow{2}{*}{ Магаданская область } & 101,9 & 198,9 & 300,8 & 96,6 & 281,8 & 378,4 \\
\hline \multirow{2}{*}{ ЕАО } & 1,0 & 4,2 & 2,0 & 0,6 & 3,7 & 1,6 \\
\hline \multirow{2}{*}{ ЧАО } & 7608,3 & 927,5 & 8535,8 & 11802,1 & 985,6 & 12787,7 \\
& 70,9 & 19,8 & 55,4 & 74,2 & 13,0 & 54,4 \\
\hline
\end{tabular}

Примечание. * Без учета импорта и экспорта услуг, поставок бункерного топлива.

Источник: составлено на основе данных таможенной статистики (не включая экспорт продукции алмазного комплекса, драгоценных металлов и изделий из них).

В 2010 г. основной экспортный потенциал региона был сосредоточен на территории Сахалинской области (74,2\% в объеме экспорта Дальнего Востока) (табл. 29). В товарной структуре экспорта области доминировала продукция ТЭК: нефть - 68,7\% и сжиженный природный газ - 25,5\%, пользующиеся стабильным спросом в странах СВА, и прежде всего, в Японии и Республике Корея. 
Распределение объемов экспорта основных видов продукции

Таблица 29 по территориям ДФО, 2010 г., \%

\begin{tabular}{l|c|c|c|c|c|c}
\hline \multicolumn{1}{|c|}{ Территория } & $\begin{array}{c}\text { Машины, } \\
\text { оборудование, } \\
\text { транспортные } \\
\text { средства }\end{array}$ & $\begin{array}{c}\text { Про- } \\
\text { ТЭКц }\end{array}$ & $\begin{array}{c}\text { Металлы } \\
\text { и изделия } \\
\text { из них }\end{array}$ & $\begin{array}{c}\text { Хими- } \\
\text { ческие } \\
\text { товары }\end{array}$ & $\begin{array}{c}\text { Лесо- } \\
\text { това- } \\
\text { ры }\end{array}$ & $\begin{array}{c}\text { Рыбо- } \\
\text { продук- } \\
\text { ция }\end{array}$ \\
\hline ДФО & 100,0 & 100,0 & 100,0 & 100,0 & 100,0 & 100,0 \\
\hline Республика Саха (Якутия) & 0,7 & 4,8 & - & - & 0,0 & - \\
\hline Камчатский край & 0,8 & - & 2,4 & - & - & 28,5 \\
\hline Приморский край & 9,1 & 0,1 & 27,4 & 96,6 & 33,5 & 36,8 \\
\hline Хабаровский край & 2,1 & 1,3 & 55,0 & 0,4 & 57,6 & 8,5 \\
\hline Амурская область & 0,8 & - & 1,3 & 0,0 & 8,0 & - \\
\hline Сахалинская область & 85,9 & 93,8 & 10,6 & 3,0 & 0,1 & 19,6 \\
\hline Магаданская область & 0,2 & - & 3,3 & 0,0 & 0,0 & 4,7 \\
\hline ЕАО & 0,0 & - & 0,0 & 0,0 & 0,8 & - \\
\hline ЧАО & 0,4 & - & 0,0 & - & - & 1,9 \\
\hline
\end{tabular}

Источник: рассчитано на основе данных ДВТУ ФТС РФ.

В отличие от экспорта, импортные потоки региона традиционно концентрировались на территории Приморского края $(65,6 \%)$, который является основным полигоном транзита импортной продукции в Дальневосточном федеральном округе (табл. 30).

Таблица 30

Распределение объемов импорта основных видов продукции по территориям ДФО, 2010 г., \%

\begin{tabular}{l|c|c|c|c|c|c}
\hline \multicolumn{1}{|c|}{ Территория } & $\begin{array}{c}\text { Машины, } \\
\text { оборудов- } \\
\text { ние, транс- } \\
\text { портные } \\
\text { средства }\end{array}$ & $\begin{array}{c}\text { Топливо, } \\
\text { мине- } \\
\text { ральное } \\
\text { сырье, } \\
\text { металлы }\end{array}$ & $\begin{array}{c}\text { Хими- } \\
\text { теске- } \\
\text { ры }\end{array}$ & $\begin{array}{c}\text { Древесина } \\
\text { и целлю- } \\
\text { лозно-бу- } \\
\text { мажные } \\
\text { изделия }\end{array}$ & $\begin{array}{c}\text { Пи- } \\
\text { совку- } \\
\text { товарые }\end{array}$ & $\begin{array}{c}\text { Прош- } \\
\text { лен- } \\
\text { ные } \\
\text { ТНП }\end{array}$ \\
\hline ДФО & 100,0 & 100,0 & 100,0 & 100,0 & 100,0 & 100,0 \\
\hline Республика Саха (Якутия) & 1,6 & 0,8 & 2,3 & 0,1 & 0,0 & 0,0 \\
\hline Камчатский край & 1,2 & 1,1 & 0,8 & 2,3 & 0,4 & 0,5 \\
\hline Приморский край & 51,8 & 36,9 & 70,6 & 80,5 & 87,1 & 84,2 \\
\hline Хабаровский край & 16,0 & 21,4 & 6,7 & 7,9 & 5,1 & 8,1 \\
\hline Амурская область & 3,6 & 2,7 & 2,8 & 3,5 & 2,9 & 4,8 \\
\hline Сахалинская область & 21,5 & 31,0 & 8,4 & 4,4 & 0,9 & 1,3 \\
\hline Магаданская область & 2,3 & 1,6 & 3,3 & 0,4 & 2,6 & 0,3 \\
\hline ЕАО & 0,4 & 0,5 & 0,2 & 0,3 & 0,8 & 0,6 \\
\hline ЧАО & 1,6 & 4,0 & 4,9 & 0,6 & 0,2 & 0,2 \\
\hline
\end{tabular}

Источник: рассчитано на основе данных ДВТУ ФТС РФ. 
№ 22011

В 2010 г. на долю Приморского края приходилось 87,1\% дальневосточного импорта пищевкусовых товаров, 84,2\% - промышленных товаров народного потребления, 70,6\% - продукции химической промышленности и свыше 50\% - машин, оборудования и транспортных средств.

В 2010 г. во внешней торговле российского Дальнего Востока, как и ранее [1; 4; 5], приоритетными оставались рынки стран Северо-Восточной Азии (рис. 7). Более того, их совокупная доля во внешнеторговом обороте увеличилась по сравнению с 2009 г. с 81,7\% до 86\%. Определенные изменения произошли и в позициях отдельных стран СВА в географической структуре внешнеторговых обменов Дальнего Востока.

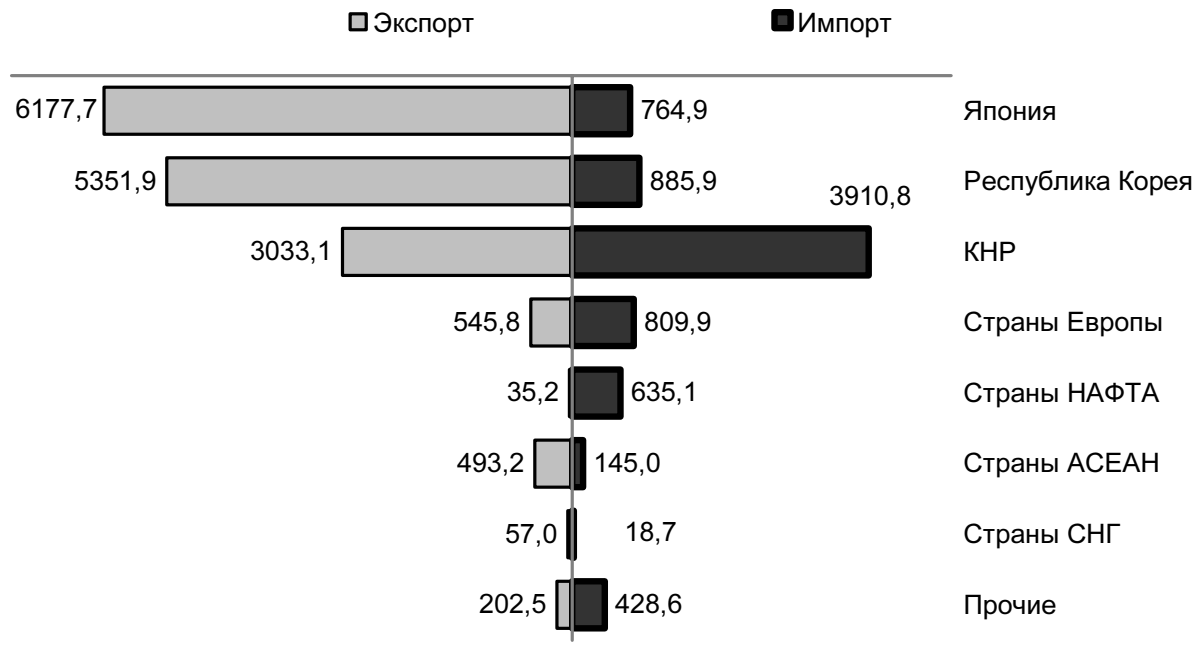

Puc. 7. Направленность товарных потоков внешней торговли российского Дальнего Востока, млн долл.

В 2010 г. ведущая роль в экспорте российского Дальнего Востока стала принадлежать Японии (38,9\%). Объем экспорта в Японию увеличился с 3,6 до 6,2 млрд долл., то есть на 72,4\% по сравнению с 2009 г. Столь значительный рост произошел за счет наращивания стоимостных объемов поставок на японский рынок дальневосточной продукции ТЭК.

В импорте региона в 2010 г. укрепил свои позиции Китай, обеспечивая потребности Дальнего Востока России в импортной продукции практически на 52\%. Вторым по значимости поставщиком продукции на дальневосточный рынок стала Республика Корея $(11,7 \%)$, объемы импорта из которой возросли относительно уровня 2009 г. в 2,3 раза.

В краткосрочной перспективе формирование объемов и структуры внешней торговли российского Дальнего Востока будет продолжать зависеть от 
динамики и структуры внешнего спроса со стороны, прежде всего, Китая, Японии и Республики Корея, а также от стабилизации экономической конъюнктуры российской экономики и скорости реализации экспортно ориентированных проектов на территории российского Дальнего Востока.

\section{СПИСОК ЛИТЕРАТУРЫ}

1. Адмидин А. Г., Деваева Е. И. Внешняя торговля и иностранные инвестиции на российском Дальнем Востоке // Проблемы Дальнего Востока. 1995. № 5.

2. Грузооборот морских портов России за 2010 год // Ассоциация морских торговых портов. www.morport.com/rus/publications/document1142.shtml.

3. Дальний Восток России: кризис преодолен // Дальневосточный капитал. 2011. № 1.

4. Деваева Е. И. Экономическое сотрудничество в СВА: региональные аспекты. Владивосток: Изд-во ДВО РАН, 2004.

5. Деваева Е. И., Котова Т. Е. Внешняя торговля Дальнего Востока России: современное состояние и тенденции развития // Пространственная экономика. 2009. № 4.

6. Итоги социально-экономического развития Амурской области. Итоги социально-экономического развития Хабаровского края // DV-Reclama.ru.

7. Мау B. Экономическая политика в 2010 году: в поисках инноваций // Экономист. 2011. № 2.

8. Мотрич Е. Л., Найден С. Н. Население и социальное развитие российского Дальнего Востока // Пространственная экономика. 2009. № 2.

9. Об итогах социально-экономического развития Российской Федерации в 2010 году. М., 2011 // Министерство экономического развития РФ. http://www. economy.gov.ru/minec/main.

10. Основные показатели социально-экономического положения регионов Дальневосточного федерального округа в январе - декабре 2009 г. Хабаровск, 2010.

11. Основные показатели социально-экономического положения регионов Дальневосточного федерального округа в январе - декабре 2010 г. Хабаровск, 2011.

12. Регионы России. Социально-экономические показатели. 2010. М., 2010.

13. Социально-экономическое положение Дальневосточного федерального округа в 2010 г. М., 2010.

14. Социально-экономическое положение Дальневосточного федерального округа в 2009 г. М., 2010.

15. Социально-экономическое положение Дальневосточного федерального округа в 2008 г. М., 2009.

16. Социально-экономическое положение России. 2010. М., 2010.

17. Федеральная служба государственной статистики. www.gks.ru.

18. Ценовой позитив на рынке леса - не повод думать о стабильности ситуации // Дальневосточный капитал. 2011. № 3. № 1.

19. Цены поддержали горнорудную отрасль // Дальневосточный капитал. 2011.

20. Шелепа А. С. Экономические проблемы развития сельского хозяйства Дальнего Востока России // Пространственная экономика. 2010. № 4. 